\begin{abstract}
UNIVERSIDADE DE BRASÍLIA.
INSTITUTO DE PSICOLOGIA

DEPARTAMENTO DE PSICOLOGIA CLÍNICA

PROGRAMA DE PÓS-GRADUAÇÃO EM PSICOLOGIA CLÍNICA E CULTURA.
\end{abstract}

LUIZA LEAL MARTINEZ

O LUGAR DO FILHO AUTISTA NO DESEJO MATERNO:

IMPACTOS E POSSIBILIDADES NA INTERVENÇÃO CLÍNICA

BRASÍLIA

2015 


\author{
UNIVERSIDADE DE BRASÍLIA. \\ INSTITUTO DE PSICOLOGIA \\ DEPARTAMENTO DE PSICOLOGIA CLÍNICA \\ PROGRAMA DE PÓS-GRADUAÇÃO EM PSICOLOGIA CLÍNICA E CULTURA.
}

LUIZA LEAL MARTINEZ

\title{
O LUGAR DO FILHO AUTISTA NO DESEJO MATERNO: IMPACTOS E POSSIBILIDADES NA INTERVENÇÃO CLÍNICA
}

Dissertação apresentado ao curso de graduação em Psicologia da Universidade de Brasília, como requisito parcial para a obtenção do Título de Mestre.

Orientador: Prof Dr Luiz Augusto Monnerat Celes 


\section{O LUGAR DO FILHO AUTISTA NO DESEJO MATERNO: IMPACTOS E POSSIBILIDADES NA INTERVENÇÃO CLÍNICA}

Comissão Examinadora:

Presidente: Professor Doutor Luiz Augusto Monnerat Celes Universidade de Brasília - UnB

Membro: Professora Doutora Viviane Neves Legnani Universidade de Brasília - UnB

Membro: Professora Doutora Daniela Scheinkman Chatelard Universidade de Brasília - UnB

Suplente: Professora Doutora Márcia Teresa Portela de Carvalho

Universidade de Brasília - UnB

Brasília, 2015. 


\section{AGRADECIMENTOS}

Ao programa de Pós-Graduação em Psicologia Clínica e Cultura da Universidade de Brasília pela oportunidade de aprimoramento de minha formação acadêmica e profissional

Ao Prof. Dr. Luiz Augusto Monnerat Celes pela atenção e disponibilidade, que foram imprescindíveis para a realização desse trabalho.

Às professoras Viviane Neves Legnani, Daniela Scheinkman Chatelard e Márcia Teresa Portela de Carvalho pela disponibilidade de participar da banca, bem como pela atenção com o meu trabalho.

Ao Conselho Nacional De Desenvolvimento Científico E Tecnológico - CNPq pela concessão de bolsa de estudos durante dois semestres letivos do mestrado.

À minha família, pelo apoio, compreensão e paciência que têm me dedicado desde sempre. E pelo constante bom humor e otimismo que tornam minha vida mais leve.

Ao Sérgio pelo amor, apoio e companheirismo que são tão importantes para $\operatorname{mim}$.

À minha analista, que esteve comigo ao longo dessa trajetória e de muitas outras.

À minha supervisora, Thais Sarmanho Paulo, cujas colocações e apontamentos são tão valiosos para minha formação.

Ás minhas sócias Loyanne Monteiro Neiva e Marina Scalco Duarte pela companhia nesse percurso tão intenso nesses últimos dois anos. 


\section{RESUMO}

MARTINEZ, L. L. O lugar do filho autista no desejo materno: impactos e possibilidades na intervenção clínica.

A presente dissertação tem por objetivo discutir qual o lugar que o filho autista ocupa no desejo materno e os impactos que esse lugar causa tanto no psiquismo materno, quanto no da criança em questão. Também tem o objetivo de discutir os aspectos particulares do tratamento na clínica do autismo, em especial em relação aos pais. $O$ método utilizado foi o de revisão bibliográfica. $O$ trabalho é dividido em quatro capítulos, sendo que no primeiro capítulo é realizada uma exposição do conceito da feminilidade ao longo do pensamento freudiano e lacaniano, de maneira a discutir o lugar ocupado pela feminilidade na teoria de cada um desses teóricos. Esse capítulo também tem a preocupação de expor os aspectos e particularidades da maternidade na sociedade contemporânea. No segundo capítulo são delineados os processos da constituição psíquica, de maneira a expor as fases de estruturação do psiquismo do bebê, trazendo as contribuições freudianas e lacanianas, de maneira a apresentar a fase do estádio do espelho proposto por Lacan. Também são expostas as discussões de autores contemporâneos sobre o tema privilegiando o ponto de vista clínico. O terceiro capítulo discorre sobre o autismo e seu tratamento clínico na psicanálise. Para isso, foi realizada uma apresentação do conceito de autismo e sua história e a apresentação da posição da teoria psicanalítica quanto suas características e tratamento. Por fim, foi discutida a posição do analista na clínica do autismo. O quarto capítulo busca discorrer sobre a maneira que as relações mãebebê se estabelecem com crianças portadoras desse transtorno, quais os impactos e efeitos que essa relação tão particular exerce sobre a mãe e quais as possibilidades de intervenção clínica nesse contexto. Nesse capitulo também foi apresentada uma breve ilustração clínica.

Palavras-chave: autismo; maternidade; constituição do sujeito; psicanálise; clínica. 


\begin{abstract}
This thesis aims to discuss what place the autistic child takes in the mother's wish and the impacts that this place cause on both the mother child psyche. Also aims to discuss particular aspects of clinical treatment of autism, particularly in relation to parents. The method used was the literature review. The work is divided into four chapters, in the first chapter a exposition of the concept of femininity is made along the Freudian and Lacanian thought in order to discuss the place occupied by femininity in theory each of these theorists. This chapter also takes care to explain the aspects and particularities of motherhood in contemporary society. In the second chapter outlined the processes of psychic constitution, to expose the phases of the baby psyche structuring, bringing the Freudian and Lacanian contributions in order to present the mirror stage phase proposed by Lacan. Discussions of contemporary authors on the subject focusing the clinical point of view are also exposed. The third chapter talks about autism and its clinical treatment in psychoanalysis. For this, was made a presentation of the concept of autism and its history and presentation of psychoanalytic theory position about its characteristics and possible treatments. Finally, we discussed the position of the analyst in clinical autism. The fourth chapter seeks to discuss the way that mother-infant relationships are established with children with this disorder, the impacts and effects that this very particular relationship has on the mother and the possibilities of clinical intervention in this context. In this chapter it was also presented a brief clinical illustration.
\end{abstract}

Key-words: autism; motherhood; subject constituition; psychoanalysis; clinic. 


\section{SUMÁRIO}

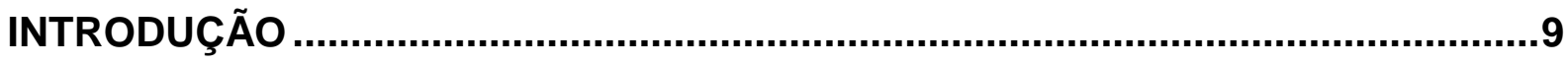

CAPÍTULO 1 - FEMINILIDADE ..................................................................17

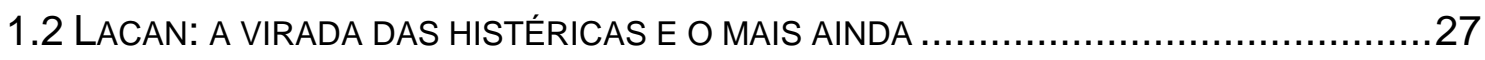

1.3 A MATERNIDADE NA CULTURA ATUAL............................................... 32

CAPITULO 2 - CONSTITUIÇÃO DO SUJEITO ……............................................35

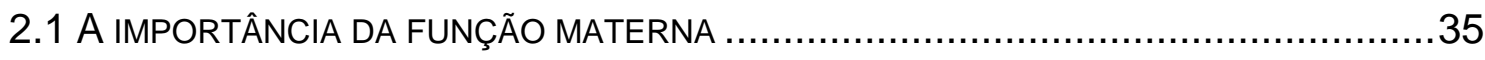

2.2 CONSIDERAÇÕES DE FREUD SOBRE A CONSTITUIÇÃO PSIQUÍCA $\ldots \ldots \ldots \ldots \ldots \ldots \ldots . . . \ldots . . . . . . .40$

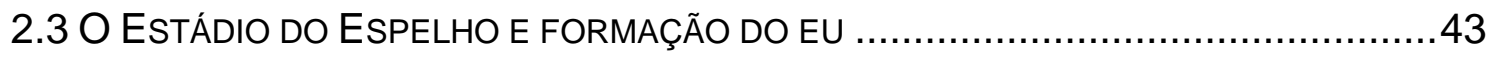

2.4 O ENLACE NA VOZ DA SEREIA: O “MANHÊS” COMO FUNDANTE $\ldots \ldots \ldots \ldots \ldots \ldots \ldots \ldots . . \ldots . \ldots . \ldots . \ldots$

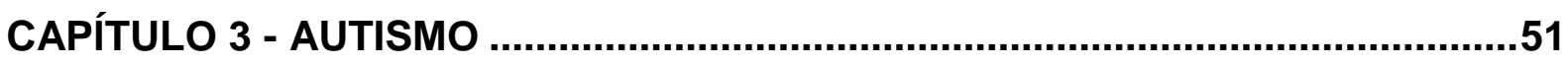

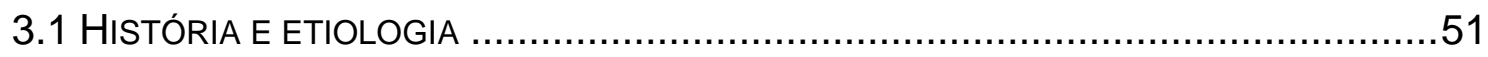

3.2 AUTISMO E PSICANÁLISE: SUA RELAÇÃO COM A CONSTITUIÇÃO DO SUJEITO E COM O

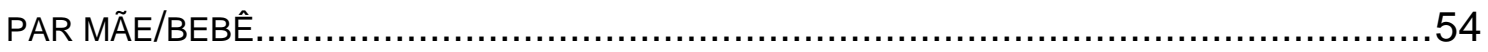

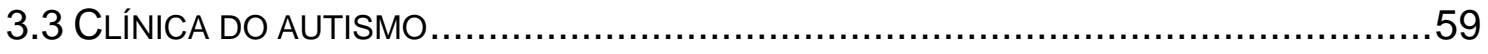


4.1 INTERVENÇÃO CLÍNICA E OS PAIS.

4. 2 CASO GABRIEL: OS EFEITOS DA RESPONSABILIZAÇÃO PARENTAL NO TRATAMENTO DE UMA CRIANÇA AUTISTA .69

CONCLUSÃO .73

REFERÊNCIAS BIBLIOGRÁFICAS .78 


\section{INTRODUÇÃO}

A maternidade é um tema que vem sendo discutido ao longo dos anos, o que resultou nas mais diversas construções, suposições e teorias acerca dela. Kehl (2008) aponta que a maternidade não possuía o mesmo peso e valor há dois séculos, sendo que hoje os filhos vêm representar maior valor narcísico para suas mães.

A autora ainda afirma que não é possível chegar a um consenso sobre o lugar da maternidade, devido às diversas mudanças que ela vem passando ao longo dos anos (Kehl, 2008). A dificuldade de definição do lugar da maternidade pode ser entendida considerando que ela está atrelada a questão da feminilidade, que traz algo de um enigma e de um incômodo por sua não apreensão (André, 1986/2011).

Freud (1933/2010) diz em Novas conferências introdutórias à Psicanálise que em relação às mulheres "elas mesmas são o enigma" (p. 265) e se propõem a responder “O que quer a mulher?”. Freud (1933/2010) tenta responder essa questão apontando as possíveis direções do desenvolvimento sexual da menina em busca de se tornar uma mulher. As principais dificuldades apontadas por ele são os processos de troca de zona erógena e objeto amoroso, que dão essa característica tortuosa. Contudo, apesar das diferenças, ambos os sexos se desenvolvem em torno da primazia do falo.

Dentre as direções apontadas por Freud, a que ele ressalta como a mais satisfatória e a única que de fato representa uma realização da sexualidade feminina normal é a maternidade. Para a mulher o filho passaria a representar um 
representante fálico e dessa forma seria uma maneira de compensar sua inferioridade frente ao masculino.

André (1986/2011) ressalta que Freud ao tentar explicar a questão feminina como a inveja do pênis, buscou um desejo único feminino de forma a formar um único conjunto de mulheres, já Lacan traz a tona uma nova questão ao ressaltar o termo "uma" mulher.

No seminário "Mais ainda", Lacan (1972-73/2008) diz que a maternidade é apenas um substituto fálico, sendo de longe a principal saída para a feminilidade. Em relação a essa temática, Lacan ressalta que outra saída fálica seria o corpo, onde ela pode se fantasiar de falo ela mesma. Partindo dessa ideia, Maia (2005) entende que a resposta à pergunta proposta acima é que a mulher deseja "fazer gozar e ser amada".

Segundo o pensamento lacaniano a maternidade é apenas uma das saídas subjetivas do feminino, é apenas uma das maneiras de gozar da mulher, já que, ela por ser não toda na inscrição fálica, pode ainda ascender a um gozo outro (Lacan, 1972-73/2008).

Podemos afirmar que ao longo dos anos outros representantes fálicos foram sendo criados e oferecidos em nossa sociedade, de maneira que a maternidade não é mais a única saída para realização das mulheres, uma delas e talvez a principal é o trabalho (Jerusalinky, J., 2009). Dessa forma o desejo de ter um bebê pode vir a significar uma ameaça às diversas outras conquistas, como formação acadêmica, independência financeira e inserção profissional (Jerusalinsky, J., 2009).

Contudo, mesmo levando em consideração que a maternidade não resume a questão do feminino é impossível negar sua importância para sujeito 
mulher. Dolto (1984/1996) discorre que a palavra mãe significa mais que uma criatura passiva ou consciente de gestar, ela é o símbolo de criatividade e fertilidade humana, de forma que, sendo a fertilidade percebida como condicionada pelo falo, ela passa a representar para si e para os outros uma imagem do falo.

Sendo assim, a maternidade é uma saída onde a mulher pode ao mesmo tempo se tornar amável e desejável para alguém e onde o bebê passe a ser 0 representante de um falo, falo esse, doado por alguém que ela acredita ser portador deste. (Jerusalinsky, J., 2009).

No que diz respeito ao papel da criança nessa saída fálica materna, Maia (2005) entende que a criança aparece como aquela que irá preencher tudo que falta a sua mãe, e para isso se oferece a ela em graus e posições variadas de forma que é capturada pelas significações do Outro.

De fato, a criança possui um lugar importante na vida da mãe, já que ela tem a possibilidade, não só de encarnar, representar o falo para essa mãe, como de possibilitar-Ihe realizar um gozo outro próprio do feminino (Laznik, 2010). Contudo é essencial ressaltar a importância desse laço mãe-bebê do ponto de vista da constituição subjetiva da criança.

Os pais são, para a criança, tradutores da cultura, carregando com eles a responsabilidade e dever de inserir esse recém-chegado ao mundo. Todavia, além desse papel de informante, a mãe, ou a pessoa que venha ocupar o lugar de função materna, é aquela que irá estabelecer seu circuito pulsional, a partir de seu próprio gozo. Veneziani (2014) traz que o bebê humano é, em si, prematuro para a vida, de forma que ele precisa ser acolhido para que possa sair do registro do orgânico e encontrar um "berço simbólico", que será propiciado a partir da palavra, e em especial os desejos de um outro. 
Contudo, é de se pensar o que ocorre quando essa criança não vem a ocupar esse lugar de objeto fálico. Uma questão que tem sido discutida com frequência atualmente é a posição das crianças autistas, que parecem não só não ocupar esse lugar, como vêm representar quase uma ferida narcísica a seus pais.

O autismo é um tema amplamente discutido e cheio de divergências entre os especialistas, sendo a principal discussão sua origem: psicogênese ou organogênese? Ou seja, ele é adquirido ao longo do desenvolvimento da criança em sua relação com o ambiente, ou é uma característica genética com o qual ela já nasce? Questão que no cenário atual ganha destaque em função dos avanços das ciências médicas e pela tendência geneticista.

Contudo, no que diz respeito à psicanálise a busca por uma causa determinante única parece impossível e altamente condenável. Esse pensamento pode ser ilustrado por Jerusalinky, A. (2014), que discorre como a causalidade psíquica pode sobrepujar aspectos de afecções genéticas e neurológicas, e possibilitar ao sujeito avanços nos aspectos sociais, educacionais e subjetivos, como ocorre com os portadores de Síndrome de Down.

Considerando esse pensamento Jerusalinky, A. (2014) afirma que:

"No terreno do autismo, por exemplo, por que, se viesse a ficar demonstrado que em todos os casos há uma causa genética e/ou neurológica - sendo que hoje sabemos (mais por confirmação clínica que por certeza genética) que essa condição causal bem provavelmente está presente numa certa proporção de autistas - a atenção dos processos de construção do sujeito neles deveria ser deixada de lado?" (p. 164). 
O termo autismo como diagnóstico, foi inicialmente proposto por Bleur em 1912, mas foi Kanner em 1943 que o popularizou ao utilizá-lo de forma a diferenciálo das deficiências mentais (Cristina Kupfer, 1999). Para ele, as crianças autistas não tinham capacidade de estabelecer relações, com frequência não tinham linguagem e as que tinham não a usavam para se comunicar, tinham reações de horror a ruídos fortes e objetos em movimento e tendiam a repetição, mas tinham boa capacidade de memória decorada e boas potencialidades cognitivas. (Cristina Kupfer, 1999).

Sendo assim, o autismo pode ser entendido como uma ausência, tanto do sujeito para ele mesmo quanto dele para o Outro. Não é a toa que as principais queixas das mães de crianças autistas são de que os filhos não olham ou falam com elas.

Cristina Kupfer entende que o autismo:

"não seria nem o efeito de uma falha genética, nem o efeito de "interações ambientais" entendidas como o faz a psicologia americana, mas uma consequência da falha no estabelecimento da relação com o Outro, quer porque o Outro materno não esteve disponível, quer porque falhou no bebê a permeabilidade biológica ao significante." (Cristina Kupfer, 1999, p. 99).

Apesar da psicanálise não se prender nas questões de causalidade psíquica, existem divergências teóricas sobre a estrutura psíquica na qual o autismo se encaixa. Os teóricos kleinianos, por exemplo, como Tustin, compreendem que ele é uma patalogia precoce que se configura como um tipo específico de organização 
psíquica, caracterizada pela ausência de linguagem e relações objetais, logo não se enquadra nas psicoses infantis e representa uma nova estrutura psíquica (Cavalcanti; Rocha).

Os teóricos lacanianos, como Marie Cristhine Laznik-Penot, Maria Cristina Kupfer e Alfredo Jerusalinsky, o entendem como uma falência da operação significante, devido a impossibilidade do Outro materno supor e antecipar o sujeito, de forma que o processo de formação do circuito pulsional e o estabelecimento de relações especulares são impossibilitados de ocorrerem (Cavalcanti; Rocha, 2001).

O presente trabalho é pautado no segundo posicionamento teórico ilustrado acima, ou seja, a partir do entendimento da teoria lacaniana. Cristina Kupfer (1999) ilustra bem esse posicionamento ao afirmar que o autista está fora do campo da linguagem e o psicótico, apesar de estar inserido na linguagem, se encontra fora do discurso. Sendo assim, eles representam tempos diferentes de uma mesma estrutura, onde na psicose o bebê se deixou capturar pelo gozo materno, e no autismo existe um fechamento, uma recusa de gozo proveniente do Outro (Laznik, 1995/2011).

Cristina Kupfer (1999) ainda afirma que Kanner logo que propôs o autismo atribuiu de forma maciça a culpa às mães, o que gerou uma revolta por parte delas. A autora ressalta que a culpabilização materna não ajudou em nada para o progresso de tratamentos com crianças autistas; contudo a não responsabilização das mesmas, amplamente sustentada pela biologização que a psiquiatria faz dos quadros autísticos, também não foi de grande ajuda.

A figura materna é de fundamental importância para a constituição do sujeito, é ela que irá fazer o papel de tradução do mundo externo para a criança bem 
como enlaçá-la em seu circuito pulsional (Jerusalinsky, J., 2009). Dessa forma, não se pode negar a importância da figura materna na vida criança, seja autista ou não.

A escolha do tema desse trabalho foi fruto de uma questão colocada pela minha experiência clínica com crianças autistas. Na minha prática pude me deparar com o sofrimento e dificuldades dos pais dessas crianças, frequentemente enevoada em uma grande apreensão frente às possibilidades do filho.

O método escolhido para discutir essa questão é o de revisão bibliográfica, de forma a estabelecer um percurso teórico de Freud a Lacan e apresentar as principais contribuições teóricas dos autores contemporâneos.

Dessa maneira, o presente trabalho tem por objetivo discutir qual o lugar que o filho autista ocupa no desejo materno e os impactos que esse lugar causa tanto ao psiquismo materno, quanto ao da criança em questão. Também tem o objetivo de discutir os aspectos particulares do tratamento na clínica do autismo, em especial em relação aos pais.

O trabalho é dividido em quatro capítulos, sendo que no primeiro capítulo é realizada uma exposição do conceito da feminilidade ao longo do pensamento freudiano e lacaniano, de maneira a discutir o lugar ocupado pela feminilidade na teoria de cada um desses teóricos. Esse capítulo também tem a preocupação de expor os aspectos e particularidades da maternidade na sociedade contemporânea.

No segundo capítulo são delineados os processos da constituição psíquica, de maneira a expor as fases de estruturação do psiquismo do bebê, trazendo as contribuições freudianas e lacanianas, de maneira a apresentar a fase do estádio do espelho proposto por Lacan. Também são expostas as discussões de autores contemporâneos sobre o tema privilegiando o ponto de vista clínico. 
O terceiro capítulo discorre sobre o autismo e seu tratamento clínico na psicanálise. Para isso, foi realizada uma apresentação do conceito de autismo e sua história e a apresentação da posição da teoria psicanalítica quanto suas características e tratamento. Por fim, foi discutida a posição do analista na clínica do autismo.

O quarto capítulo busca discorrer sobre a maneira que as relações mãebebê se estabelecem com crianças portadoras desse transtorno, quais os impactos e efeitos que essa relação tão particular exerce sobre a mãe e quais as possibilidades de intervenção clínica nesse contexto. Nesse capitulo também foi apresentada uma breve ilustração clínica. 


\section{CAPÍTULO 1 - Feminilidade}

A feminilidade é um tema que foi e ainda é muito discutido dentro da psicanálise. Esse grande interesse, quase fascinação, ocorre pelo fato da mulher ser entendida como um enigma, algo a ser decifrado. Tanto que ela é colocada em uma constante oscilação, ora cultuada por seu enigma, seu mistério, ora odiada por sua mistificação, seu mentira (André, 1986/2011).

André (1986/2011) em seu livro "O que quer uma mulher?" coloca essa questão de forma muito clara: "O que significa "ser uma mulher"? Eis aí a Questão por excelência, para qual evidência alguma nos oferece seu apoio, como quando se trata de saber o que é um homem." (p. 10).

\subsection{Freud, a feminilidade e a cultura.}

Freud discorreu sobre a feminilidade em diversos trabalhos em busca desse enigma, o qual ele mesmo reconheceu não ter sido feliz em decifrá-lo. Sua primeira construção sobre o tema é nos "Três ensaios sobre a sexualidade" (1905/1996) onde faz os primeiros apontamentos acerca da sexualidade infantil e começa a discorrer sobre as diferenças de desenvolvimento entre os sexos.

Ao longo desse texto ele traz que a suposição de que todos têm o pênis é a primeira das grandes teorias sexuais infantis, tanto para a menina, quanto para 0 menino. Contudo a menina frente à ausência do pênis não se ilude e de pronto 
reconhece não possuí-lo e assim culmina em uma inveja do mesmo, o que trará importantes consequências. (Freud, 1905/1996).

Ainda nesse texto, discorrendo sobre as zonas erógenas, ele afirma que, inicialmente, a da menina é o clitóris, que equivaleria à glande da zona genital masculina. Ele aponta que o clitóris tem papel central no entendimento do processo de transformação da menina em mulher, pois diferentemente do menino, que na puberdade tem uma elevação da libido e permanece com o pênis como zona erógena principal, a menina passará por uma nova onda de recalcamento que afetará a sexualidade do clitóris, de forma a substituí-la pela sexualidade vaginal.

Dessa maneira, na puberdade irá ocorrer uma transferência da excitabilidade erógena do clitóris para a vagina, logo a mulher muda a zona dominante para sua atividade sexual, enquanto o homem conserva a mesma desde a infância. Essa mudança de zona dominante e a onda de recalcamento da puberdade eliminam a masculinidade infantil, o que viria a ser causa da propensão das mulheres a neurose, em especial a histeria (Freud, 1905/1996).

Freud volta a tratar do desenvolvimento sexual feminino em "A organização genital infantil" (1923/2010), onde aponta que para ambos os sexos o que vale é um único genital, o masculino, mas o que existe, de fato, não é uma primazia genital, e sim, uma primazia do falo. Considerando isso, ele ainda afirma que o complexo de castração só pode ser apreciado corretamente se levar em conta tal primazia.

menino ao se deparar com a ausência do pênis nas pessoas do sexo feminino teoriza que apenas aquelas que são indignas, que são culpadas de impulsos proibidos não o têm, e que mulheres dignas como sua mãe ainda o 
possuem. Sendo assim, o genital feminino parece jamais ser descoberto (Freud, 1923/2010).

Em seguida em "A dissolução do complexo de Édipo" (1924/2010) ele volta a falar dessa não descoberta do genital feminino ao falar da fase fálica, que é impulsionada pelo genital masculino, devido ao mistério do feminino.

A diferença da castração na menina e no menino é que a primeira a compreende como um fato consumado e o segundo como uma possibilidade de castração. Apesar da menina reconhecer sua castração, a renúncia ao pênis não é admitida sem uma tentativa de compensação. Ela realiza uma equação simbólica na qual caminha do pênis ao bebê, de forma que o complexo de Édipo culmine no desejo de receber do pai o falo como presente, ao Ihe gerar um filho (Freud, 1924/2010).

Entretanto com a não realização desse desejo, o complexo de Édipo vai aos poucos sendo abandonado, mas os dois desejos, ter o pênis e um filho, permanecem fortemente investidos no inconsciente, o que ajuda a preparar esse ser feminino para seu futuro papel sexual. (Freud, 1924/2010)

Levando em conta que a aceitação da castração não ocorre de maneira fácil, Freud descreve o que ele chama de complexo de masculinidade na menina, onde ela acredita que seu membro ainda não cresceu, mas que ainda se desenvolverá (Freud, 1924/2010). Contudo, essa crença não se sustenta e ela passa a compreender que ela já possuiu o membro, mas que o perdeu com a castração.

No ano seguinte, Freud publica "Algumas consequências psíquicas da diferença anatômica entre os sexos" (1925/2010), onde ele vai dar início às descrições das características assimétricas do desenvolvimento do menino e da 
menina e passa a questionar o lugar da mãe para o desenvolvimento sexual da menina.

De início havia uma crença de que o desenvolvimento sexual infantil na menina se passava de forma semelhante ao do menino com algumas diferenças, mas não havia clareza de onde essas diferenças se operavam.

Diferente do menino que tem a mãe como objeto sexual inicial e assim a mantém durante o complexo de Édipo, na menina ocorre uma complicação que seria o fato que seu objeto inicial também é a mãe, o que faz indagar o que a faria abandonar a mãe e assumir o pai como objeto. Dessa forma, Freud vem ressaltar a importância da investigação dos processos pré-edípicos na menina.

A menina vê o pênis de seu irmão ou algum outro menino e reconhece-o como superior ao seu próprio órgão, o que suscita uma inveja do pênis. Dessa maneira ela faz seu julgamento e toma uma decisão: "ela viu, sabe que não tem e quer ter" (Freud, 1925/2010, p. 291). A partir dessa operação ocorre o que é chamado de complexo de masculinidade na mulher, que se não for logo abandonado, pode trazer prejuízos ao desenvolvimento rumo à feminilidade. Nesse complexo a menina recusa-se a admitir a castração e se agarra a convicção que possui o pênis, de forma que se vê impelida a agir como um homem.

Outra forma de lidar com a inveja do pênis, que não seja pelo complexo de masculinidade é que após superar a primeira explicação da falta do pênis como castigo pessoal e infortúnio particular, ela reconhece a universalidade dessa característica e passa, assim como o homem a partilhar um menosprezo pelo "sexo reduzido", de forma, que ao menos nesse sentido ela permanece equiparada ao homem (Freud, 1925/2010). 
A terceira possível consequência da inveja do pênis é que a menina compreenda que foi a mãe que não lhe ofertou o pênis e que a colocou no mundo tão pouco aparelhada (Freud,1925/2010). É aqui que começa a surgir a queixa e a hostilidade frente à mãe, que não a supriu o suficiente e que futuramente será colocada como rival (Freud, 1933/2010) .

Freud (1925/2010) irá ressaltar diversas vezes que a condição para o desenvolvimento da sexualidade feminina é a eliminação da sexualidade clitoridiana. No complexo de Édipo a libido da menina passa por uma equação simbólica de pênis=criança, de forma que ela assume uma nova posição. Ela abandona o desejo de possuir um pênis e o substitui pelo desejo de ter uma criança.

A partir da finalidade desse desejo ela toma o pai como objeto amoroso, de forma que a mãe passa a ser objeto de ciúme, já que a menina, passa a rivalizar com a mãe pelo lugar de mulher desse pai. Essa operação só é possível, devido ao reconhecimento da menina frente à castração, ou seja, de sua diferença frente ao menino, o que a faz abdicar de seu equivalente inferior ao pênis, o clitóris, e buscar outras vias de resolução fálica.

Na menina o complexo de Édipo é uma formação secundária, sendo ele sucessor do complexo de castração. Essa importância do complexo de castração na menina pode ser compreendida a partir do fato que esse complexo age de maneira a inibir e limitar o masculino e promover o feminino. É por isso, que o complexo de Édipo do menino sucumbe à castração, enquanto o da menina é inaugurado por ele (Freud, 1925/2010).

Freud (1925/2010) traz que, devido a forma em que o Édipo feminino se organiza, o Super-eu da mulher jamais se torna tão inexorável e impessoal, de forma que as mulheres têm menor inclinação a submeterem-se às exigências da vida e 
são mais guiadas por sentimentos afetuosos e hostis. Ele atribui essas características ao fato do complexo de Édipo feminino não ter, de fato, uma razão para acabar, como acontece com o masculino que decai frente a ameaça da castração. Na mulher a castração já foi realizada e é ela que inaugura e permite sua entrada no mesmo, sendo assim, não existe ameaça que a faça abandoná-lo.

Em 1933 nas "Conferências introdutórias à psicanálise”, Freud reserva um espaço para discorrer sobre essa temática resultando na publicação de "A feminilidade" (1933/2010) e frisa com veemência que o caminho que a mulher faz ao longo de seu desenvolvimento sexual é mais tortuoso e complexo do que o percorrido pelo homem.

Quanto à dificuldade a mais da menina em relação ao menino no desenvolvimento sexual, ele afirma que isso ocorreporque a garota deve realizar duas tarefas a mais, que não existem em correspondência na evolução do menino (Freud, 1933/2010). Uma das tarefas a mais a ser cumprida pela mulher rumo a feminilidade é a concessão do clitóris, antes principal zona erógena na fase fálica, à vagina, que ocupará o papel principal na sexualidade da mulher.

A segunda operação é a de mudança de objeto. Para ambos os sexos a mãe é o primeiro objeto amoroso, já que ela, ou seus equivalentes nessa função, são o primeiro investimento objetal, investimento esse que se apoia na satisfação das grandes e pequenas necessidades vitais. Contudo, para a menina o objeto amoroso na cena edípica é o pai, de forma que se o desenvolvimento transcorrer de forma normal a escolha objetal definitiva acontecerá a partir do pai como modelo de objeto (Freud, 1933/2010).

Dessa maneira, a menina, para seguir o curso do desenvolvimento sexual rumo à feminilidade, deve realizar tanto a troca objetal da mãe pelo pai, quanto da 
zona erógena do clitóris pela vagina. Contudo, a questão que é colocada é como esse processo se desenvolve e o que a leva abandonar tanto a mãe como objeto amoroso, quanto sua satisfação clitoridiana (Freud, 1933/2010).

A menina de início entende que sua castração é uma desgraça pessoal, contudo com o tempo passa a atribuí-la aos demais seres femininos, incluindo a mãe. Sendo assim, ela se decepciona com essa mãe, já que seu amor era dirigido a mãe fálica eao percebê-la faltosa ela a abandona como objeto e se dirige rumo ao pai.

O afastamento em relação à mãe ocorre sob o signo da hostilidade, sendo que essa hostilidade tem a intensidade relacionada com o alto grau de ambivalência nas primeiras relações objetais, de forma que junto ao amor intenso existe uma grande inclinação agressiva tão intensa quanto este. Sendo assim, quanto mais a criança ama um objeto, mas sensível ela se torna às decepções por ele causadas.

Os desejos dirigidos ao pai provêm do desejo anteriormente endereçado a mãe de ter o pênis e como esse desejo não foi suprido, ela se volta ao pai com a esperança de recebê-lo. Entretanto, a "situação feminina" só se estabelece quando a equivalência simbólica entre o pênis e a criança ocorre, de forma que a criança venha ocupar o lugar no desejo anteriormente ocupado pelo pênis (Freud, 1933/2010).

No desejo de ter um bebê do pai, o mais importante é o fato que este pode vir a realizar uma equivalência ao pênis anteriormente desejado. Dessa maneira, mesmo na sexualidade feminina dita "normal", o desejo masculino pelo pênis permanece. Sobre essa questão, Freud (1933/2010) chega a enunciar que 
"deveríamos talvez reconhecer tal desejo de pênis como um desejo feminino." (p.285).

Com a transferência do desejo bebê-pênis para o pai, a menina adentra o complexo de Édipo. A mãe, já hostilizada por ter frustrado a menina, agora passa a ser alvo de uma rivalidade por parte dela em função da disputa pelo amor desse pai. Dessa maneira é possível perceber que a cena edípica é, para a menina, o resultado de um longo e difícil desenvolvimento (Freud, 1933/2010).

Nas “Conferências introdutórias à psicanálise”, Freud (1933/2010) resgata e organiza diversas elaborações expostas em outros trabalhos de sua autoria, mas é interessante chamar a atenção para sua definição de masculino e feminino.

Desde os "Três ensaios sobre a sexualidade", Freud (1905/1996) ressalta a dificuldade de delineamento dos conceitos de feminino e masculino. Neste trabalho ele arrisca afirmar que a libido é regular e normativamente de origem masculina, seja no homem ou na mulher. Oito anos mais tarde ele vai desenvolver esse pensamento, de forma que irá afirmar que no estágio pré-genital não é possível, ainda, falar de feminino e masculino e sim de ativo e passivo. Já no estágio de organização genital infantil, o que ocorre não é a oposição entre masculino e feminino, mas sim entre não-castrado e castrado.

Sendo assim, apenas após a puberdade a polaridade sexual irá coincidir com masculino e feminino, onde o masculino significa a atividade e posse do pênis e o feminino assume o lugar da passividade, onde a vagina, significada como o abrigo do pênis, "torna-se herdeira do ventre materno" (Freud, 1923/2010, p. 175).

Nas "Conferências introdutórias à psicanálise", Freud (1933/2010) reafirma a descrição de masculinidade como se referindo a ativo e a feminilidade a passivo, mas faz questão de ressaltar que essa equivalência se mostra insatisfatória 
na vida sexual humana, já que, são posições subjetivas que podem ser assumidas por um ou outro em situações particulares.

Dessa maneira, mesmo afirmando no mesmo texto que a feminilidade poderia ser pensada como a preferência por metas passivas, Freud deixa a brecha de metas e posições ativas para a mulher. Todavia, como ressalta Neri (2005), sob o julgo do desvio.

Freud (1924/2010) reconheceu que a feminilidade é muito mais complexa do que ele pode apreender, assumindo que suas conclusões sobre os processos de desenvolvimento sexual da menina ainda eram obscuros e cheio de lacunas. Em "A feminilidade" (1933/2010), além de reconhecer a incompletude de seus estudos sobre o tema, ele faz um convite para o debate e investigação do mesmo. Entretanto, tal retratação não o poupou das críticas dos que o sucederam.

Dentre as críticas, Kehl (2008) aponta Margarete Hilferding, uma discípula de Freud, que traz em uma conferência a não instintividade e inevitabilidade do amor materno. Ela assinala que o bebê vem sim a representar um objeto sexual para a mãe, mas que a constituição dele como objeto não é garantida e está, como todos os outros objetos, sob o julgo da relação objetal, ou seja, suscetível à possibilidade de decepção frente ao mesmo.

Birman (2001) busca compreender quais são os aspectos que influenciaram os estudos freudianos sobre o feminino, levando em conta o contexto e a época. Ele afirma que o pensamento freudiano do ponto de vista libidinal assume que sem a maternidade a mulher não seria mulher de fato, e que o pleno encontro com a feminilidade só ocorreria com a assunção da maternidade, pensamento que parece corroborar com a sociedade vitoriana. 
O autor ressalta que o feminino encontra uma representação forjada na modernidade de maneira polarizada, onde de um lado a maternidade representa um agente civilizatório e o erotismo um processo anticivilizatório, de forma que o segundo seria sempre um problema no ser da mulher (Birman, 2001).

Kehl (2008) também apresenta essa preocupação de compreender a mulher freudiana e ressalta que, a partir do século XVII e XIX, existia uma grande preocupação com o papel da mulher na sociedade. Esta deveria seguir sua natureza e destino como procriadora e cuidadora e inevitavelmente mãe. Ela traz que isso pode ser compreendido como uma medida de contenção da desorganização social frente à ascensão da burguesia.

Kehl (2008) analisando o texto de Emílio de Rousseau diz: "A mulher, que em seu puro "estado de natureza" pode ser reduzida à força de seu sexo, deve ser especialmente domesticada para que seus "desejos ilimitados" não destruam a ordem social e familiar." (p. 60). Essa posição frente ao feminino mostra o horror causado pela figura enigmática da mulher, e corrobora para as medidas disciplinadoras impostas às mulheres nessa época, mulheres essas que alguns anos mais tarde foram objeto de estudo da psicanálise.

Birman (2001) ressalta que apesar da abertura de possibilidades para outras figurações femininas na sociedade no século XIX, as mulheres que faziam opção por não trilhar o caminho da maternidade eram culpabilizadas.

Neri (2005) entende que as primeiras elaborações freudianas sobre a feminilidade apontam para a neurose e frigidez, já que esse seria o efeito de seguir o destino verdadeiramente feminino da maternidade, onde o horizonte aparece como de uma mãe e esposa passiva, neurótica e frígida. 
Com as mudanças do século $\mathrm{XX}$, as contribuições de Freud, que já haviam sido criticadas em sua época, passam a perder sentido, já que os psicanalistas passam a se depararem com mulheres com novas questões, sendo essas para muito além da maternidade (Neri, 2005).

\subsection{Lacan: a virada das histéricas e o mais ainda}

Lacan é um dos clínicos que se depara com essas novas mulheres e seus novos estilos de existir, o que não passa desapercebido por ele. Em 1960 no texto "Diretrizes para um congresso sobre a sexualidade feminina", ele fala de uma "negligência marcante" por parte da psicanálise em relação à sexualidade feminina. Essa declaração apesar de não representar uma inauguração frente ao tema da feminilidade para Lacan, marca sua posição frente ao tema, de forma que ele irá se debruçar sobre o mesmo em variados momentos ao longo de sua obra, de maneira a abrir o leque de possibilidades ao feminino.

Neri (2009) afirma que a postura de Lacan frente ao feminino foi fruto da transformação que a histeria sofreu ao longo dos anos desde os tempos de Freud. As enfermidades femininas da era vitoriana apresentavam um quê de passividade e prostração. Enquanto nos casos com os quais Lacan teve contato era possível ver mulheres enfurecidas, loucas e sedentas para dizer algo sobre elas mesmas.

Logo, como ressalta Lacan (1955-56/1988), não é a toa que a questão "o que quer uma mulher?" costuma ter maior incidência, ser mais questionada na histeria, como é possível observar no caso Dora. Caso, do qual Freud confessou seu erro ao identificar o objeto de amor de Dora, já que ele se apressou em perguntar 
quem ela desejava, antes de se questionar quem desejava em Dora (Lacan, 1955$56 / 1988)$.

Birman (2001) ressalta que o que caracteriza a histeria é a oposição entre os registros da maternidade e do erotismo, onde a mulher histérica se recusa a identificar-se com a maternidade permeada "de fio a pavio" pela dimensão erótica. Logo, o discurso pautado na maternidade como grande resolução pulsional cai por terra frente às histéricas.

Lacan, em relação ao complexo de Édipo aponta que Freud fez grandes esforços de buscar pontos em comuns para os caminhos de desenvolvimento do menino e da menina, mas nunca deixou de apontar a dessimetria entre os sexos, sendo a causa, a razão de tal dissimetria situada no nível simbólico, já que, ela depende do significante, o falo (Lacan, 1955-56/1988).

Lacan (1955-56/1988) ressalta que o complexo de Édipo para mulher não ocorre de forma simétrica ao do homem, e isso não se deve à identificação com a mãe e sim à identificação com o objeto paterno, que lhe possibilita um desvio suplementar.

"Mas a desvantagem em que se acha a mulher quanto ao acesso à identidade, seu próprio sexo quanto à sexualização como tal, na histeria transforma-se numa vantagem, graças à sua identificação imaginária com o pai, que lhe é perfeitamente acessível, em virtude especialmente de sua posição na composição do Édipo." (p. 202).

Lacan (1955-56/1988) coloca que a questão “o que é ser uma mulher?", "o que é um órgão feminino?", se coloca como algo singular, de interesse e indagada tanto pela mulher, quanto pelo sujeito macho. 
André (1986/2011) traz que apesar da afirmação de Freud de que tanto o menino e a menina não reconhecem a materialidade da vagina, ele afirma que eles a conhecem bem como um órgão e pedaço do corpo, contudo ela não é reconhecida como significante no nível do significante como sexo feminino.

Sendo assim, não existe um significante que defina o feminino, da mesma maneira que o significante fálico define o masculino. Logo a mulher está sempre em busca de algo que a defina.

André (1986/2011) ressalta que Freud ao tentar explicar a questão feminina como a inveja do pênis, buscou um desejo único feminino de forma a formar um único conjunto de mulheres, já Lacan traz a tona uma nova questão ao ressaltar o termo "uma" mulher.

No seminário 20 "Mais ainda", Lacan (1972-73/2008) se debruça sobre o feminino e é nele que ele irá debater sobre a inexistência da mulher. Nesse seminário ele propõe o seguinte quadro, abaixo, que consiste em uma representação gráfica da relação entre o homem e a mulher, já que ele afirma que não há relação sexual.

Essa afirmação se deve ao fato de que não é possível se relacionar com o outro no real, já que nos relacionamos com a imagem, com a representação desse outro para si e vice versa. Então, de fato, não existe relação interpessoal de tipo algum. 


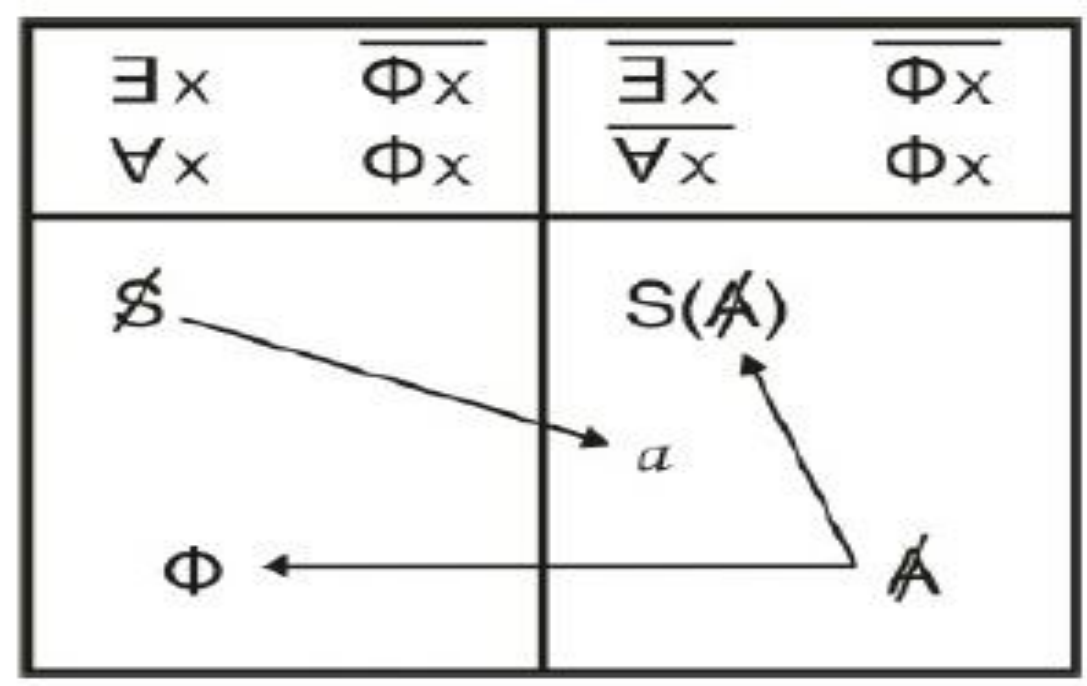

Figura: Recuperado de Lacan (1972-1973/1985, p. 105)

O lado esquerdo do quadro representa o lado masculino, sendo que a primeira função significa que existe um sujeito para quem a função fálica não se inscreve, logo existe um homem não castrado. E a segunda significa que para todo sujeito a função do falo se inscreve, logo todo homem está submetido à função fálica e todo homem é castrado.

Já no lado direito, o lado da mulher, a primeira função significa que não existe sujeito para quem a função do falo não funcione, logo não existe mulher não castrada. E a segunda significa para não todo sujeito é verdadeiro que a função do falo funcione, logo a mulher não é toda submetida à castração.

Já na parte inferior do quadro, do lado do homem, é possível ver o símbolo da função fálica e o movimento do homem como sujeito barrado se dirigindo ao objeto a, objeto causa de desejo no campo da mulher.

$\mathrm{Na}$ parte inferior do quadro da mulher, é possível perceber que ela, um Outro barrado, logo dividida e não toda, possui duas saídas: ou ir em direção a função fálica e usufruir do gozo fálico; ou de um gozo outro, um gozo que opera pela vertente do significante do Outro barrado. 
Logo a mulher não existe porque ela não se inscreve de uma forma universal. Como ela não pode ser definida apenas pelo significante fálico, ela não possui um significante que a defina por inteira. É devido a essa inscrição não toda que Lacan propõe que a mulher tem um gozo para além do gozo fálico, chamado de gozo Outro ou gozo místico (1972-73/2008).

André (1986/2011) traz que, - Lacan nos seminários “... ou pior”, Mais ainda, e em L'Etourdit - a divisão do sujeito perante ao sexual não se dá pela divisão de dois sexos, e sim, pela divisão entre dois gozos, um todo fálico e outro não, onde o primeiro faz o segundo surgir como um "a mais".

Kehl (2008) cita Madame Bovary, obra de Flaubert, onde afirma que as várias máscaras de feminilidade apresentadas pela personagem ao longo do romance, aparecem como uma "intuição" do autor de que não existe A Mulher, de forma que a feminilidade é um conjunto de representações que tentam produzir uma identidade entre todas as mulheres, mas que por isso não podem dar conta de cada sujeito.

A ideia freudiana de que a maternidade resolveria o problema do complexo de masculinidade e inveja do pênis, sugere uma naturalização do desejo materno, já que, supõe que tal desejo seria capaz de resolver de forma espontânea questões vividas de forma tão particular por cada sujeito. (Jerusalinsky, J., 2009). Esse pensamento desconsidera a pluralidade de saídas, sempre criativas, que a mulher pode ter acesso para lidar com tais questões, não só devido ao feminino, mas pelo seu estatuto de sujeito desejante.

Lacan ao propor outra forma de gozo à mulher amplia ainda mais as escolhas de gozo feminino, por isso ter um filho passa a ser apenas uma das formas 
de gozo fálico, uma forma importante e muito valiosa, mas apenas uma das opções de uns dos gozos possíveis à mulher.

\subsection{A maternidade na cultura atual}

Rassial (2005) citando Freud ressalta que o período da puberdade se caracteriza para a mulher como uma regressão narcísica, contudo essa reativação narcísica está longe de não incluir o Outro, já que, o que ocorre é um engajamento no olhar do Outro. A adolescência na menina, "aponta o que pode ser visto pelos outros" (RassiaL, 2005, p. 25).

A tão característica exibição feminina encontra seu fundamento nesse jogo especular, já que ela vem se oferecer ao olhar do Outro como objeto (Rassial, 2005). Dolto (1984/1996) entende que na puberdade ocorre uma intensificação da distribuição pulsional, onde o corpo é investido como um corpo fálico plástico, de forma que assinala o interesse dos homens de uma maneira completamente indiferenciada. Ou seja, ela vem se apresentar como objeto a esses que a olham, e fazendo esse movimento se diferencia diante do homem. Ainda sobre essa questão, Rassial (2005) discorre que:

“Assim, em relação ao falo, e portanto, à distribuição dos sexos, ela terá que se situar não como aquela que possui, mas como aquela que o faz aparecer, mesmo que seja porque, trivialmente, é apresentando-se como desejável que ela permite o exercício fálico, no outro." ( p. 26). 
Considerando esse desejo de ser vista e se fazer desejada pelo outro, a maternidade aparece para a mulher como uma possibilidade de se tornar amável e desejável para alguém, onde "o bebê ocupa o lugar de um falo que the foi doado por alguém que ela supõe como portador do falo." (Jerusalinsky, J., 2009, p.124).

Dolto (1984/1996) discorre que a palavra mãe significa mais que uma criatura passiva ou consciente de gestar, ela é o símbolo de criatividade e fertilidade humana, de forma que, sendo a fertilidade percebida como condicionada pelo falo, ela passa a representar para si e para os outros uma imagem do falo.

Jesusalinsky (2009) traz que a gestação costuma trazer à mulher um intenso sentimento de prazer e realização, entretanto ela também representa um reencontro com sua própria condição feminina já que ela, mulher tem de revisitar a castração materna agora em uma posição de mãe e não mais de criança.

Dolto (1984/1996) aponta que a gestação e a maternidade "trazem ao corpo da mulher o perigo ou segurança da identificação genital com sua mãe" (p. 106), já que, existe uma grande alteração no seu investimento, que se descentra de seu próprio corpo, até agora seu único representante fálico, para o da criança.

Contudo, ao longo dos anos outros representantes fálicos foram sendo criados e oferecidos em nossa sociedade, de maneira que a maternidade não é mais a única saída para realização das mulheres, uma delas e talvez a principal é o trabalho (Jerusalisnky, J., 2009). Sendo assim, mesmo que ter um bebê ainda seja desejável, esse desejo esbarra e ameaça outras conquistas e pré-condições, como formação acadêmica, independência financeira e inserção profissional (Jerusalinsky, J., 2009).

Kehl (2008) traz que a maternidade não possuía o mesmo peso e valor há dois séculos, sendo que hoje os filhos vem representar maior valor narcísico para 
suas mães, essa supervalorização da criança para sua mãe nem sempre esteve presente. No caso do século XIX, o contexto era de mães que trabalhavam, ou de mães ricas que eram desencorajadas, inclusive, a não se ocuparem dos cuidados dos filhos, de forma a delegar os cuidados aos empregados, o que era visto como um sinal de status.

Jerusalinsky, J. (2009) ainda aponta que a maternidade está longe de ser uma resolução tranquila de como lidar de forma substitutiva com a falta, ela relança a mulher à angústia de castração e a divisão diante dos diferentes modos de gozo. Em outras palavras, a maternidade atualiza para a mulher "sua condição de nãotoda no gozo fálico"(Jerusalinsky, J., 2009, p.132)

Dessa forma, apesar de existirem novos representantes fálicos com os quais a mulher pode escolher tamponar sua falta, a maternidade não deixou de ter o estatuto de importância como equivalente fálico. Talvez pelo valor social, ou ainda como bem apontou Freud, pelo valor narcísico de poder produzir e amar uma parte sua. 


\section{CAPITULO 2 - Constituição do sujeito}

O ser humano é o único animal do mundo que nasce incompleto e completamente dependente de um outro para sua sobrevivência. Ele é por essência um ser que nasce prematuro, sendo que sua maturação está longe de estar completa.

Para além da imaturidade orgânica, o novo ser se depara com um mundo que já vinha rodando há muito tempo antes de sua existência. Sendo assim,ele além de um cuidador, necessita de um guia, um tradutor desse novo mundo em que acaba de chegar. Só assim tem a possibilidade de abandonar seu estado de feixe de nervos e advir como um sujeito.

Esse papel de tradutor e cuidador é atribuído à função materna, função essa que pode ser exercida não somente pela mãe, mas por qualquer um que esteja disposto a ocupá-la.

\subsection{A importância da função materna}

O papel da função materna tem fundamento na questão biológica e isso se deve à prematuridade do ser humano, que nasce sem condições alguma de sobrevivência. Contudo, diferentemente dos outros animais que fazem uma "cobertura" às suas crias e as abandonam assim que elas têm condições de sobreviverem sozinhas, a relação complexa estabelecida entre adulto e bebê vai 
além da questão da sobrevivência, de forma que tal relação, denominada "laço mãe/criança", possibilita o advento psíquico do bebê (Cullere-Crespin, 2004).

A constituição psíquica é um processo complexo e que demanda um enorme esforço e investimento dos envolvidos, ou seja, do próprio bebê e daqueles que o cercam. Cullere-Crespin (2004) aponta que com frequência a complexidade desse processo não é compreendida a "olho nu", pois para aqueles que observam um bebê que se desenvolve normalmente, sem muitas dificuldades em seu caminho, podem ser enganados pelo que a autora chama de "aparente simplicidade do normal" ou "opacidade do normal", quando, na realidade, esse bebê pode se desenvolver e advir sujeito, graças ao investimento psíquico e desejo de sua mãe e de seus demais cuidadores.

Jerusalinsky, A. (1984/2012) define função "o que faz função é aquele fator que determina todas as outras variações em relação ao qual, por oposição, se diferenciam os demais elementos." (p. 13). Logo, a função materna é a mediadora entre o bebê e o mundo, é partir dela que a criança, de início, olhara e compreenderá o mundo.

Winnicott (1956/1978) fala da fase inicial do relacionamento mãe-bebê onde não existe uma diferenciação ou compreensão do bebê enquanto um ser independente, compreensão que só pode ser alcançada em um segundo momento. O autor propõe o que ele chama de "preocupação materna primária", que seria uma "doença" que a mãe sofre entre o período do fim da gestação e após algumas semanas do nascimento do bebê, e que se caracteriza por uma sensibilidade exacerbada às necessidades do bebê já nos seus primeiros momentos (WINNICOTT, 1956/1978). Um bom exemplo dessa disponibilidade é trazido a partir 
da fala de uma mãe citada por Debray (1988): "cada bebê tem necessidade de ter sua mãe para si um tempo suficiente" (p. 93)

Cullere-Crespin aponta que para a mãe entrar em contato com seu bebê é necessário que ela o tome como parte de si, de forma que ela atribua a esse bebê conteúdos psíquicos e de maneira que, nessa relação fusional, ela sabe sobre esse bebê da mesma maneira que ela sabe sobre si mesma. Dessa forma, ocorre uma efração simbólica, uma forçagem do simbólico materno sobre o bebê. Esse movimento é fundamental e constitutivo, pois é a partir da palavra da mãe que esse bebê pode passar a existir como sujeito (Cullere-Crespin, 2004).

É partir da sensibilidade própria desse estado fusional que é possível que a mãe possa sentir-se no lugar de seu bebê, ou seja, se identificar com ele, e assim poder corresponder as suas necessidades. Necessidades essas que, de início são meramente corporais, mas que gradativamente se transformam em necessidades do ego "à medida que da elaboração imaginativa das experiências físicas emerge uma psicologia" (Winnicott, 1956/1978, p. 403).

Dessa forma, a figura materna é de fundamental importância para a constituição do sujeito, é ela que irá fazer o papel de tradução do mundo externo a criança bem como enlaçá-la em seu circuito pulsional (Jerusalinsky, J., 2009).

Considerando que existem mulheres mais ou menos dispostas a ocuparem essa posição materna, é importante frisar que existe uma enorme diferença entre a identificação da mãe com o bebê e a dependência do bebê em relação a mãe (Winnicott, 1956/1978). Isso ocorre não só porque, como ressaltou Winnicott (1956/1978) a dependência não implica na identificação, por ser um processo demasiadamente complexo para ser identificado nos primeiros estágios de 
vida do bebê, mas também devido à disponibilidade que essa mãe tem de se identificar com o seu bebê.

Winnicott (1956/1978) defende que a mãe seria aquela que estaria mais apta a cuidar do bebê devido a essa "doença" que ela se permite passar. Contudo é possível entender que todo aquele que esteja disposto a sustentar a "doença" da preocupação materna primária, estaria apto a cuidar desse bebê, na medida em que possa se identificar com ele. Dessa maneira, para ser mãe ou ser maternal é necessário um alto grau de identificação com o bebê, lembrando, claro, que a mãe mantém sua condição de adulto ao fazer essa identificação (Winnicott, 1967/1997).

Cullere-Crespin ressalta que não basta que aquele que cuida do bebê seja semelhante, é preciso que ele seja prestativo, ou seja, é preciso que ele sustente, seja portador do desejo de sobrevivência do recém-nascido. Sendo que esses cuidados exercidos pela mãe não são de fonte objetiva ou instrutiva, mas sim de registros inconscientes: "Os registros primitivíssimos e inconscientes da maneira de como o Outro cuidou dela quando ela própria era bebê serão, em grande parte, os registros aos quais uma mulher fará apelo ao cuidar de seu bebê" (CullereCrespin, 2004, p. 23).

A autora ainda aponta que o fato do bebê humano possuir necessidades que são compreendidas como demandas que desejam, a partir do momento que este entra em contato com o outro em uma relação, ele abandona o estatuto da necessidade e passa a funcionar no registro do desejo.

Freud já havia ressaltado isso ao propor que o bebê sente prazer em se inundar, para além do leite, do Outro nutridor, movimento que ele chamou de experiência primordial de satisfação (Cullere-Crespin, 2004). Em outras palavras se institui aí a pulsão no lugar da necessidade. 
Sendo assim, é possível observar o bebê abdicar de suas necessidades em prol de seu desejo, o que pode ser exemplificada com a anorexia, dessa forma a existência prevalece sobre a sobrevivência (Cullere-Crespin, 2004).

Winnicott (1956/1978) ressalta o que ele chama de ambiente suficientemente bom, que possibilita o desenvolvimento do bebê, onde ele pode alcançar as satisfações, ansiedades e conflitos pertinentes a cada etapa, e um ambiente não suficientemente bom, que distorce e atrapalha o desenvolvimento do bebê.

Cullere-Crespin (2004) propõe que a função materna e função paterna são antagonistas complementares que guardam as operações fundadoras do psiquismo do bebê, onde a primeira corresponde à alienação e a segunda à separação e que é a partir da articulação dialética entre as duas que é possível estabelecer trocas satisfatórias com o bebê.

A autora fala da importância da função paterna que permite que o bebê se descole da mãe e passa a ser entendido como um outro, sendo assim ele passa a ser menos previsível e compreensível, pois ele não é mais parte dela, mas um outro também desejante (Cullere-Crespin, 2004). Sendo assim, uma mãe que não se posiciona na vertente paterna, ou não permite que alguém o faça, permanece em sua onipotência primordial, ou seja, permanece como única detentora do saber sobre seu bebê, já que, este ainda faz parte dela. (Cullere-Crespin, 2004).

Em relação a essas funções, a autora coloca que existem duas séries de sinais que ilustram o sofrimento precoce do bebê, ou seja, assinalam o momento em que as funções materna e paterna não estão bem equilibradas e organizadas (Cullere-Crespin, 2004). Uma das séries é a "série barulhenta" que tem o intuito de alertar aqueles que estão próximos e correspondem a um ato do bebê, onde ele é 
ativo e luta contra um excesso materno (Cullere-Crespin, 2004). Nesses casos a mãe se mostra intrusiva e não se observa uma vertente paterna, deste modo o próprio bebê vem exercer essa função paterna, de maneira a conter a onipotência materna (Cullere-Crespin, 2004).

A outra série é a "série silenciosa", que, ao contrário da barulhenta, pode passar despercebida e, inclusive, ser confundida com um aspecto positivo (CullereCrespin, 2004). Nessa série o bebê deixa de lutar para pôr limite à onipotência materna e se entrega a uma passividade e atonia, que podem ser convenientes e confortáveis para os cuidadores, o que a torna mais perigosa (Cullere-Crespin, 2004).

\subsection{Considerações de Freud sobre a constituição psíquica}

No "Projeto para uma psicologia científica", Freud (1895/1996) busca descrever o processo de formação e funcionamento do aparelho psíquico. Nesse mesmo texto ele estabelece o desamparo infantil como constituinte da subjetividade, já que é a partir da inabilidade de se satisfazer que resta ao bebê o choro. Em outras

palavras, o corpo sente fome e pede satisfação dessa necessidade, o bebê, que é incapaz de satisfazê-la por si, chora e alguém responde a esse choro.

Logo o choro é a primeira mensagem do bebê ao outro, sendo que ela só é mensagem, porque alguém atribui esse estatuto. Podemos pensar no que Lacan (1953-54/1996) diz sobre o apelo, que só é realizado se dirigido a um outro e é a partir dele que a dependência se instala. 
Nos "Três ensaios sobre a sexualidade", Freud (1905/1996) ressalta a importância das relações estabelecidas entre a criança e as pessoas que despendem cuidados a elas. A relação da criança com a pessoa que cuida dela é uma fonte de extrema satisfação sexual e tem uma função de extrema importância para seu desenvolvimento sexual, já que, ela se configura como um ensaio do que vem se realizar mais tarde a partir da entrada no primado genital. Dessa forma, a mãe ao despender cuidados à criança, a esta ensina a amar, o que mais tarde será de fundamental importância para seu desenvolvimento sexual e sua escolha de objeto.

A puberdade vem inaugurar a era do primado genital. É a partir dela que o sujeito sai da satisfação autoerótica e olha a sua volta no ímpeto de buscar a realização sexual fora de seu corpo. Contudo, essa busca de um encontro com um objeto na verdade se caracteriza como um reencontro, já que o sujeito já estabeleceu uma relação com um objeto fora de seu corpo, que seria o corpo da mãe.

No texto "Introdução ao narcisismo", Freud (1914/2010) afirma que as primeiras satisfações sexuais do bebê estão ligadas as funções de autoconservação, o que faz com que os primeiros objetos sexuais da criança sejam as pessoas que estão encarregadas de sua nutrição, cuidado e proteção. Esse movimento faz com que todo ser humano tenha originalmente dois objetos sexuais: ele mesmo e a mãe, a pessoa que lhe oferece cuidados. Logo, o narcisismo primário advém do par mãe-bebê.

Além dessa consideração sobre o narcisismo do bebê, Freud ressalta a importância do narcisismo dos pais, pois esse cuidado e amor oferecido à criança é uma revivência do próprio narcisismo dos pais que há muito foi abandonado. Tanto 
que os pais tendem a atribuir ao filho todas as perfeições e desejam lhe ofertarem tudo que é bom e privá-lo de tudo que é mau. Esse cuidado pode ser entendido como amor, já que, o amor é o seu próprio eu que se ama, já que é o seu próprio eu realizado no imaginário (Lacan, 1953-54/1996).

Em “Além do princípio do prazer”, Freud (1920/2010) descreve e analisa uma brincadeira de uma criança de 18 meses. Esse menino com o desenvolvimento normal e descrito como comportado brincava sozinho com um carretel. Quando jogava o carretel entoava "o-o-o-o", interjeição que se assemelha com a expressão "fort", que significa foi embora. Ao puxar o carretel de volta ele entoava "da", de aqui está. Sendo esse segundo momento aparentemente de maior prazer que primeiro.

Freud interpretou esse jogo como uma encenação da presença-ausência da mãe. Logo ele representava uma renúncia pulsional, já que o bebê se utiliza de um substituto para obter satisfação. A menção desse jogo é importante, pois ele possui um estatuto de jogo constituinte, ou seja, um movimento de encenação de ensaio pulsional que só pode ser estabelecido por causa do par mãe-bebê

Ele sugeriu três motivos pelo qual o bebê se engaja nesse jogo, sendo o primeiro a alternância entre prazer e desprazer, já que para que o primeiro exista é necessário o segundo. A segunda hipótese é o de troca de lugar, onde ele deixa de ocupar uma posição passiva frente às ausências maternas e pode controlar, decidir quando essa mãe vai e volta. E a terceira seria uma forma de se vingar dessa mãe que o abandona, de forma ele possa mandá-la embora ao invés de ser abandonado. Jerusalinsky, J. (2009) chama a atenção para a importância desses jogos constitucionais para o bebê, pois eles permitem que ele saia do gozo em direção ao saber,de forma que ele saia da posição de objeto para a de sujeito. 


\subsection{O Estádio do Espelho e formação do eu}

Uma das grandes contribuições de Lacan foi sua formulação teórica à qual ele chamou de estádio do espelho. Tanto o esquema quanto menções a esse estádio percorrem toda sua obra à medida que ele debate diversos conceitos.

O estádio do espelho consiste em uma formulação teórica de Lacan na qual ele ilustra a formação do eu a partir de um esquema óptico. O esquema que ele se utiliza é o esquema de boasse, no qual é realizado o experimento do buquê invertido.

O processo de maturação fisiológica permite ao sujeito em um dado momento integrar suas funções motoras e aceder a um domínio real do seu corpo. Só que antes de isso ocorrer o sujeito toma consciência de seu corpo como uma totalidade mesmo que de uma maneira correlativa (Lacan, 1953-54/1996). E é exatamente sobre isso que se trata o estádio do espelho, essa antecipação da totalidade do corpo.

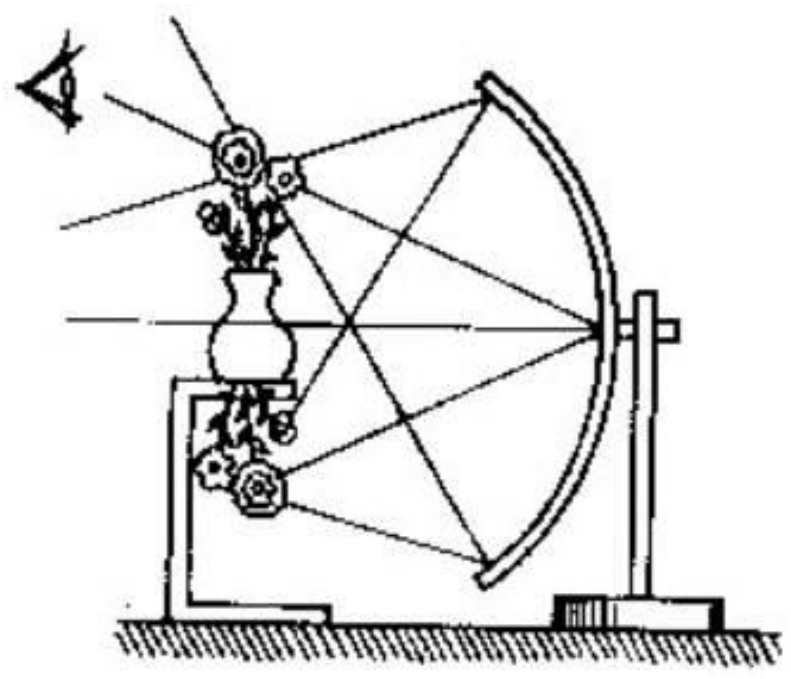

Figura 1 Seminário 1 p. 94 
Nesse experimento o observador tem a sua frente um vaso e escondido embaixo da mesa se encontra um buquê. Logo só é possível ver o vaso, enquanto o buquê está escondido. Com a utilização de um espelho côncavo a imagem do buquê é refletida e projetada de forma invertida sobre o vaso, de maneira que o observador passa a ver, além do vaso, o buquê. Contudo, enquanto a imagem do vaso é real, a do buquê é virtual.

Lacan utiliza esse jogo óptico como uma analogia ao fato que o filhote humano, ainda em atraso, pode ver sua imagem refletida no outro. $O$ outro oferece a ele a imagem unificada dele mesmo, de forma que antecipa a esse bebê apreender essa imagem, antes que organicamente e cognitivamente seja capaz de fazê-lo.

Sendo assim, a imagem total formada pelo espelho côncavo é semelhante a imagem que o outro oferece ao bebê de seu próprio corpo, fazendo assim que a simples visão desse corpo todo possibilite ao sujeito um domínio imaginário do seu corpo, ainda prematuro em relação ao domínio real (Lacan, 1953$54 / 1996)$.

O espelho côncavo vem para explicar a junção do organismo da criança adido do investimento libidinal dos pais, ele (o espelho côncavo) vem nos dar a experiência perceptiva dos pais. Laznik (2004) afirma que "um corpo supõe algo projetado sobre ele, algo que não faz parte do "objeto real"- que posso tocar, pesar -, mas que é uma imagem, uma "imagem real" projetada a partir de algo do aparelho psíquico dos pais, que não está no bebê" (p.161).

Lacan (1953-54/1996) descreve uma contribuição de Melanie Klein sobre como a criança se funde no continente materno e como ali produzirá seu mundo. Nesse continente existirão objetos, podendo esses objetos serem bons ou perigosos 
para ela. Sendo esse perigo proveniente, por espelho, dela mesma, já que ela atribui a esses objetos a mesma destrutividade de que ela se sente capaz. Sendo assim, esse é o primeiro movimento de limitações do eu, já que ela irá rejeitar esses objetos como maus e perigosos.

Ele afirma que a imagem do corpo possibilita ao sujeito começar a distinguir o que faz ou não parte de seu eu. Logo, é o reconhecimento dessa imagem que permite a ele se separar do Outro materno.

As funções do eu devem passar por uma alienação fundamental que "constitui a imagem refletida de si mesmo, que é o Ur-Ich (eu primordial), a forma original do Ich-Ideal (eu-Ideal) bem como a relação com o outro" (Lacan, 195354/1996, p 148). Essa operação faz coincidir uma imagem real com o objeto que está nele. Sendo assim o corpo estruturado, ainda não existente, coincide com o corpo despedaçado do real.

Com a formação do eu primordial o bebê pode, então, se diferenciar do outro, movimento que vai também ser possibilitado pela ausência de Outro para a criança. É o movimento do fort-da, onde a ausência do outro passa a ser mais um demarcador da diferença entre ele e a criança.

Laznik (2004) concorda com a importância da escansão presença ausência do outro ressaltada por Lacan, contudo destaca que é necessário que exista uma presença fundadora para que posteriormente ocorra ausência, em outras palavras, ela afirma a importância do olhar fundador do Outro.

A principal característica desse Outro primordial é a de poder antecipar, tanto para si, quanto para o bebê, aquilo que ainda não surgiu nessa criança. Ele é "aquele capaz de ouvir o que o bebê ainda não disse; de ver aquilo que ele ainda não é” (Laznik, 2004, p 166) 
A posição do "olho" tem a ver com a posição no simbólico, se os pais tem um bom posicionamento eles podem ver o bebê como um todo, se a posição não for adequada, mais deformada será a imagem, logo mais difícil de apreenderem a imagem completa do bebê.

O esquema óptico representa as instâncias do organismo, e é assim que devemos olhar para elas. Sendo que o que apreendemos desse sistema são meras imagens, sejam elas reais ou virtuais. O espelho côncavo reflete uma imagem real do vaso, imagem que irá envolver o buquê de flores, dando uma unidade, um reflexo da unidade do corpo. Logo o que aparece é o primeiro narcisismo, que se relaciona a imagem corporal, dá forma ao seu mundo interno, sendo que sua imagem é idêntica ao conjunto de mecanismos psíquicos do sujeito (Lacan, 1953-54/1996).

O vaso é o corpo e as flores o investimento libidinal. Esse investimento libidinal é nomeado por Lacan de falicização do bebê: "Esta unidade que se constitui no olhar do Outro fundador, é a pré-forma (Uhrib) do corpo do bebê." (Laznik, 2004 P. 162).

Laznik em A voz da sereia (2004) propõe uma adaptação do esquema óptico de Lacan. Nele ela substitui o vaso, que no original representa o organismo do bebê, pela imagem do próprio bebê. E substitui o buquê, que representa o investimento libidinal dos pais, por uma coroa de flores. Dessa maneira o resultado da imagem completa é um bebê coroado por flores, ou seja, o corpo do bebê. 


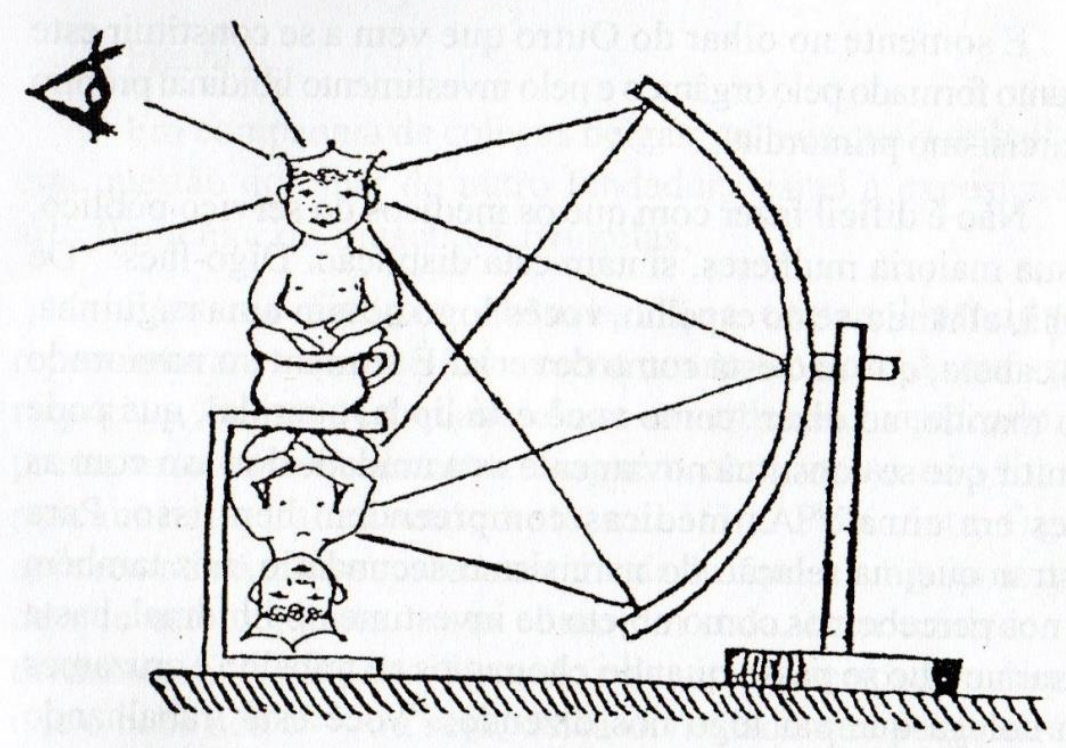

Dessa forma quando o bebê volta-se para o olhar dos pais encontra o orgânico aureolado pelo investimento do qual ele é objeto (Laznik, 2004).

Laznik (2004), na sequência da apresentação de sua adaptação do esquema óptico de Lacan, traz à luz os três tempos pulsionais do bebê, como coparticipante desse processo de formação do eu. No primeiro tempo o bebê busca, de forma ativa, o seio ou a mamadeira. O segundo tempo é caracterizado como autoerótico, já que o bebê busca se satisfazer através de processos autocalmantes, como chupar o dedo ou a chupeta. O terceiro tempo é o "fazer-se", se oferecer para o Outro (Laznik, 2004). Esse terceiro tempo está relacionado com o desejo do bebê de ser comido, devorado por esse outro.

Esse terceiro tempo era descrito por Freud como passivo, contudo essa passividade é, em si, ativa, já que o bebê, apesar de se colocar em uma posição passiva, assim o faz se oferecendo para o Outro, é o tempo do se fazer (Laznik, 2004). 
Quando esse terceiro tempo falha, o circuito pulsional não é completado, não é possível fazer uma relação entre o segundo e o terceiro tempo, o que pode impossibilitar um autoerotismo sem Eros, que é a marca do laço com o Outro (Laznik, 2004).

Laznik (2004) chama a atenção para essa questão fazendo um jogo de palavras: Autoerotismo - Eros $=$ autismo . Logo, não é sem motivo que Lacan se utiliza do caso Dick de Melanie Klein para exemplificar a construção do imaginário.

Catão (2014) afirma que um corpo de significantes sozinhos não faz corpo, o que constitui o corpo é a organização dos significantes. O que é organizador do corpo não é o que é dito postulado sobre ele, mas o movimento de dizer algo sobre ele, é a enunciação. Contudo para que esse movimento ocorra ele tem de ser de mão dupla entre o Outro primordial encarnado pela mãe e o bebê.

Um significante sozinho não faz corpo, pois significante nenhum por si só é passível de sentido, ele só passa a ter sentido em cadeia com outros significantes, logo essa é a importância da enunciação, é o deslizamento.

\subsection{O enlace na voz da sereia: o "manhês" como fundante}

Existem várias discussões sobre a importância da voz materna para o bebê, estes geralmente relacionados com as propriedades calmantes que exercem sobre a criança, como é o caso do calor e do cheiro. Entretanto, para além dessa importância do âmbito do cuidado das necessidades, a voz materna carrega uma potência de instalação de demanda na criança. 
Os psicolinguistas chamam de protoconversação os turnos de fala durante os quais a mãe ocupa alternadamente o lugar do bebê, ao traduzir os sons que ele produziu (Laznik, 2004). Laznik (1995/2011) ressalta que entre a mãe e o filho se estabelece uma língua da relação dual, que não tem lei e que é portadora do bem querer da mãe.

Essa língua é o "manhês", e se caracteriza como uma forma particular que a mãe dirige a palavra ao seu filho, onde ocorre uma subversão das regras gramaticais buscando uma forma mais clara e fácil de oferecer a palavra ao bebê. Tanto que a apreensão da língua materna é uma castração, já que obriga o bebê a abandonar essa língua da relação dual em prol de uma língua imersa e fruto da cultura, de uma língua submetida à lei. (Laznik, 1995/2011)

Catão (2014) também chama a atenção para a importância da voz materna na estruturação do bebê:

"É a mãe quem sustenta para o bebê a incorporação do significante, costurando o campo da linguagem ao real do corpo da criança. E ela o faz por meio de sua voz. Ela fala com ele e por ele. O bebê chama, é chamado e se faz chamar, respondendo à invocação e demonstrando, deste modo sua implicação no gozo do outro. Pois não basta que haja gozo materno. É preciso uma implicação do bebê. Eis deste modo instaurado o circuito da pulsão invocante, experiência que serve de primórdio à estruturação inconsciente como uma linguagem." (p. 238-239). 
Laznik (2004) descreve experimentos realizados com bebês recémnascidos ao ouvirem gravações da voz da mãe. Eles se demonstram atentos e capturados por essa voz, mesmo antes da primeira mamada. Contudo, a reação frente à gravação é bem menor do que com a mãe pessoalmente. Isso se deve ao fato de que a mãe só pode falar o "manhês" na presença de seu bebê, já que quando essa fala é endereçada a outro, a mãe diminui ou retira toda prosódia e melodia endereçada ao bebê, afinal seu "manhês" perde a função.

As reações descritas nos experimentos citados acima denotam que desde o nascimento o bebê tem uma apetência extraordinária para o gozo que desencadeia no Outro materno, mesmo antes de qualquer experiência de satisfação alimentar (Laznik, 2004).

Não é a toa que a as principais características do "manhês", que tanto interessam ao bebê, são a surpresa e a alegria presentes nele. É o júbilo, o gozo do Outro materno que o captura como a voz da sereia (Laznik, 2004). 


\section{CAPÍTULO 3 - Autismo}

\subsection{História e etiologia}

O autismo é algo que está em pauta na atualidade, seja pelo aumento de diagnósticos dessa síndrome, seja pelo desconforto que ele provoca. Nos últimos anos o número de crianças autistas subiu consideravelmente, contudo não é possível afirmar se a incidência desse tipo de transtorno cresceu ou se mais diagnósticos são fechados sobre esses casos.

Isso fez com que o interesse acerca desse tema crescesse muito, o que resultou em um aumento de mais de seis vezes no número de artigos publicados sobre o tema entre 1997 e 2011 (Solomon, 2013).

O Código Internacional de Doenças - CID 10 - classifica o autismo como um transtorno global do desenvolvimento identificado como f84.0 - autismo infantil, sendo suas características as seguintes:

"Transtorno global do desenvolvimento caracterizado por a) um desenvolvimento anormal ou alterado, manifestado antes da idade de três anos, e b) apresentando uma perturbação característica do funcionamento em cada um dos três domínios seguintes: interações sociais, comunicação, comportamento focalizado e repetitivo. Além disso, o transtorno se acompanha comumente de numerosas outras manifestações inespecíficas, por exemplo: fobias, perturbações de sono ou da alimentação, 
crises de birra ou agressividade (auto-agressividade)." (Organização Mundial Da Saúde, 1997).

O termo autismo foi inicialmente proposto por Bleur em 1912 para caracterizar um transtorno que se diferenciava da esquizofrenia infantil. O objetivo dele com essa nomenclatura era frisar os comportamentos de isolamento dessas crianças, já que, Autismo vem do grego auto "referente a si mesmo", mais o sufixo ISMOS, indicando ação ou estado (Cavalcanti; Rocha, 2001).

Contudo é possível observar relatos de crianças com esses sintomas antes dessa denominação, como e o caso do pequeno Dick de Melanie Klein (1930). Criança diagnosticada com esquizofrenia infantil, mas cuja sintomática e funcionamento se assemelham muito com as das crianças autistas.

Kanner retomou o termo proposto por Bleuer ao propor uma nova síndrome na psiquiatria infantil "o distúrbio autístico do contato afetivo" que mais tarde adotou o nome autismo (Cavalcanti Rocha, 2001). Ele afirmava ter escolhido esse termo para enfatizar a solidão extrema dessas crianças (Solomon, 2013)

Ele incluiu nessa nomenclatura crianças que ele caracterizou como inteligentes, com excepcional capacidade de memorização, incapacidade inata para estabelecer contato afetivo e quando apresentam linguagem, essa se apresenta ecolálica, irrelevante, sem sentido e não utilizada para comunicação (Cavalcanti; Rocha, 2001).

Kanner abriu uma vertente que foi e ainda é veementemente criticada, que é a das mães geladeiras, que consistia em atribuir as mazelas dessas crianças à mãe frias e pais altamente intelectualizados. Isso gerou revolta por parte das mães, que se sentiram profundamente culpabilizadas e atacadas. 
Na psicanálise, Bruno Bettelheim é apontado como um teórico que compartilhava do mesmo pensamento de Kanner em relação às mães. Apesar de concordar quanto o papel da mãe no surgimento do autismo, Bettelheim discordava da origem orgânica do autismo, atribuindo-o exclusivamente a incapacidade da mãe de cuidar de seu bebê. Ele ainda chegou afirmar de forma categórica que: "O fator desencadeante do autismo infantil é o desejo dos pais de que o filho não exista" (Bettelheim, 1927, apud Solomon, 2013 p.275).

A teoria de Bettelheim gerou grande revolta nas associações de pais autistas na época e passou a ser vista como um pensamento geral da psicanálise e desde então o psicanalista passa a ser visto como um "acusador de mães" (Ferreira, 2014).

Buscando amenizar essa situação Kanner publica em 1950, "Em defesa das mães", onde busca se redimir das afirmações feitas anteriormente, contudo nesse trabalho ele descreve e propõe um modelo do que seria uma boa mãe, o que perpetua a cobrança em relação às mães.

Atualmente, existem divergências muito grandes sobre as causas do autismo, geralmente colocadas entre a psicogênese e o organogênese. Contudo, independente das causas, o que não pode ser deixado de lado é o sofrimento das crianças e adultos portadores desse funcionamento.

Uma boa ilustração desse sofrimento é o poema da autista Jennifer Franklin ressaltado por Solomon (2011) no livro Longe da árvore:

"Eu não só

Te perdi num instante

Abandonei as infinitas possibilidades

Do que podia ter sido" (p. 299) 


\subsection{Autismo e psicanálise: sua relação com a constituição do sujeito e com o par mãe/bebê}

Cavalcanti e Rocha (2001) afirmam que da mesma maneira que a histeria foi para Freud o principal objeto de estudo e a psicose, para os kleinianos e lacanianos, o autismo vem ocupar esse lugar para os psicanalistas contemporâneos.

Por muito tempo, e ainda em algumas linhas teóricas é defendido, ou pelo menos citado o conceito de "mães frias" ou "mães geladeiras", de forma a atribuir a sintomática e causas do autismo a mães ruins ou não desejosas. Contudo, como bem fala Jerusalinky, A. (1984/2012), discorrer sobre causalidade psíquica parece infrutífero e inconclusivo. Quando se trata do sujeito, e não só nessa temática, é impossível e imprudente fazer previsões.

Jerusalinsky, A. (2014) chama a atenção que o organicismo e a culpabilização das mães não levam a lugar algum. $O$ autor cita 0 exemplo dos portadores de síndrome de Down quanto a essa questão:

"O atualmente clássico exemplo da Síndrome de Down no que tange à sua notável evolução social, educacional e subjetiva sem que sua base genética tenha sido alterada - evolução produzida totalmente desde o âmbito da causalidade psíquica é acompanhada hoje por uma vasta lista de afecções genéticas e neurológicas nas quais a causalidade psíquica pode retornar com um efeito progressivo ou deteriorante segundo as circunstancias que se ofereçam para o afetado e segundo o 
modo em que se signifiquem sua causalidade e consequências." (Jerusalinsky, A., 2014, p. 163).

Jerusalinsky, A (2014) vai além questionando o que ocorreria se ficasse comprovado que em todos os casos de autismo existe uma causa genética ou neurológica. Ele afirma que independente da causa, o trabalho do analista permanece o mesmo, afinal já foi demonstrado que o grau de expressão de condições genéticas iniciais pode ser modificado pela intervenção do outro. E que decretar a prion a impossibilidade do autista de se constituir como sujeito do seu próprio desejo não faz sentido algum, afinal é só tomarmos o exemplo da Síndrome de Down citado acima.

O pensamento do autor está de acordo com o de Lacan (1955-56/1980) que, no "Seminário 3 - As psicoses", afirma categoricamente que a psicanálise não supõe uma psicogênese das doenças mentais.

Ferreira (2014) concorda com essa posição e afirma que independentemente dos fatores envolvidos ou não no autismo, sejam genéticos ou ambientais, nada invalida a particularidade de que ali se encontra um sujeito em constituição como ser falante. E isso é o suficiente para justificar o lugar da clínica psicanalítica no campo do autismo.

Laznik (2004) afirma que a discussão entre a psicogênese e organogênese é um falso debate, que o interesse dos analistas deve se voltar para aquilo que ela chama de prevenção, sendo que no caso do autismo essa prevenção se dá intervindo na relação do Outro com a criança.

O autismo não tem o título de síndrome à toa, já que não ocupa os requisitos básicos para ser incluído como uma doença que seria a causa comum, 
incidência e quadro sintomático estabelecido (Solomon, 2013). Contudo é possível perceber que existem dois fatores que se mostram contundentes no surgimento do autismo que são: o fato da mãe não conseguir sustentar o mundo simbólico para a criança; e a criança que está organicamente impedida de chegar a se constituir (Jerusalinsky, A., 1984/2012).

O aparecimento do autismo está intimamente ligado ao desequilíbrio do encontro do agente materno com a criança. Devido a não conseguir sustentar o simbólico frente ao filho, o espelho oferecido joga a criança na esfera do real novamente (Jerusalinsky, A., 1984/2012).

Independente da causa, o que se observa nos casos de autismo é a falha da delicada operação de entrada no campo da linguagem. Existe uma falha na função primordial de reconhecimento. Em outras palavras, se estabelece um obstáculo intransponível entre a criança e seu Outro primordial (Jerusalinsky, A., 1984/2012).

Para Laznik (2004) no autismo existem indícios de que as estruturações necessárias para o estabelecimento do aparelho psíquico não estão se fazendo. Sendo assim, é sabido, entre aqueles que trabalham com autismo, que existe uma corrida contra o tempo, já que quanto mais cedo a intervenção ocorrer maiores são as possibilidades de estruturação do aparelho psíquico, mesmo que previamente essa estruturação não tenha ocorrido.

Catão (2014) ressalta que a estruturação do corpo e do psiquismo ocorrem concomitantemente, não existindo um sem o outro. Contudo, o que se percebe nas crianças autistas é uma maturação e crescimento orgânico normais e a instalação de um funcionamento psíquico muito particular. Esse impasse instalado 
tão cedo na estruturação psíquica não permite que seja possível garantir que estamos diante de um corpo sustentável (Catão, 2014).

No estádio do espelho, o bebê aos seis meses sorri à sua imagem refletida e procura no olhar da mãe ou do pai a validação daquilo que ele vê no espelho. Experiência do "olhar fundador do grande Outro" (Laznik, P.160)

Entretanto no autismo isso não se consolida, existe um impedimento na entrada do estádio do espelho (Jerusalinsky, A., 1984/2012). Devido a não entrada no estádio do espelho o autismo consiste na ausência do imaginário/simbólico propriamente dito (Jerusalinsky, A., 1984/2012).

Laznik (2004) em seu trabalho com médicos ressalta dois aspectos que acredita serem mais facilmente assimiláveis por eles: sendo o primeiro, o não olhar entre a mãe (Outro primordial) e o filho, em especial se essa mãe não percebe esse não olhar, o que demonstra uma falha no circuito pulsional ver-ser visto; e o segundo, o fracasso do terceiro tempo da pulsão oral, ou seja, no processo de se oferecer ao gozo do Outro.

Logo, como foi citado por outros autores, existe aí um problema na entrada do estádio do espelho e na formação de seu circuito pulsional. A criança autista fica operando em um curto circuito psíquico, onde suas possibilidades se mostram muito tolhidas.

Ao nascer, o ser humano é puro automatismo biológico, onde o bom funcionamento desses automatismos frente à cultura leva a normalidade, enquanto 0 mau funcionamento leva a dificuldade para a obra do significante (Jerusalinsky, A., 1984/2012).

importância é importante levar em conta que a linguagem é nada mais que uma memória coletiva externa ao corpo, um código de leis, é ela que vem 
substituir os automatismos biológicos e que ajuda o sujeito a rumar para a "normalidade". Contudo no autismo o que ocorre é um fracasso na construção das redes de linguagem (Jerusalinsky, A., 1984/2012). Por isso o desconforto, a invasão quando o outro lê seus automatismos como letra.

Jerusalinsky, A. (1984/2012) cita Yanklevich (2004) que afirma que é necessário retirar o autista do 'ovo do autoabastecimento', em outras palavras é necessário resgatá-lo do autoerotismo, de forma a invadir seus automatismos biológicos. Tanto que é dai que advém o desconforto e recusa do autista frente ao mundo, já que o Outro invade ao tentar ler seus automatismos (Jerusalinsky, A., 1984/2012).

Bem como o processo de constituição, não é possível precisar os sintomas autísticos e defesas maternas. Essa tentativa de encontrar o ponto onde se desenrola os sintomas é infrutífera, já que não é possível, considerando a complexidade desse processo. A constituição é a própria incerteza, já que é aquilo que vai para o campo do Outro.

Podemos fazer alusão ao processo descrito por Freud (1895/2006) no texto "Projeto para uma psicologia científica", onde ele explica a falta de memória nos primeiros anos de vida, devido à falta de experiências suficientes para compor uma cadeia associativa. Em outras palavras, uma cadeia significante. Sendo assim, essas experiências existiram, mas a não associação não as permitem se fixarem como memória. Ou seja, é um processo do qual não se tem certeza de quando se consolidará qual o número de experiências necessárias para poder fixar uma memória.

A constituição tem algo de semelhante com esse processo, já que ela é um "andar", é para além de soma, uma interação entre todos os jogos constituintes e 
fatos fundantes pelo qual a criança e a mãe se engajam. Mistura da qual aos poucos, mas sempre de surpresa advém um sujeito.

\subsection{Clínica do autismo}

Jerusalinsky, A. (1984/2012) é categórico ao dizer que o genético não deve atuar como um limite para a perspectiva clínica, só se pode saber os limites de um caso até que se tente algo.

Laznik (1995/2011) aponta que é possível ver os efeitos de uma psicoterapia precoce sobre os sinais eletrocenfalográficos de uma criança, o que denota a complexidade da intricação entre orgânico e psíquico nas síndromes autísticas. Onde é possível perceber que o fato de algumas funções primeiras não terem se instaurado podem ter repercussões orgânicas contundentes, mas eventualmente reversíveis se tratadas cedo.

Catão (2008) afirma que a constituição do corpo é uma resposta à invocação do Outro, onde a criança tenta com seu corpo desvendar o enigma de seu lugar no desejo do Outro. É a velha pergunta "o que queres de mim?" A partir desse processo é que o bebê pode se apropriar de seu corpo e começar a falar sem saber o que diz. (Catão, 2014).

Desse modo, considerando as peculiaridades desse processo de instalação da fala a partir de seu próprio corpo, a escuta analítica das produções sonoras das crianças autistas, mesmo que essas possam parecer insignificantes, possibilitam a emergência de uma fala que ela, a posteriori, pode reconhecer como sua (Laznik, 1995/2011). 
Laznik (1995/2011) cita Lacan (1963): “A comunicação como tal não é o que é primitivo já que, na origem, o futuro sujeito nada tem a comunicar, porque todos os instrumentos da comunicação estão do outro lado, no campo do Outro, e ele tem de recebê-los dele" (p.20). Logo, o analista pode escutar as produções sonoras de uma criança autista mesmo que ela não tenham função de comunicação, tanto é possível que o bebê também se encontra nessa situação de dissimetria e é a partir do Outro que ele pode advir como sujeito (Laznik, 1995/2011).

Barros (2014) aponta que "no autismo, há um eu que fala repetidas vezes a espera de um parceiro tu que se torne seu eco" (p.171). A sua esperança é que esse parceiro possa redefinir sua produção linguageira e a lance de volta para ele.

Contudo, o que ocorre é uma dificuldade de alternância entre eu e tu, também consequência do fato de não existir um outro que reconheça essa possibilidade de movimento discursivo, e ao lançar o autista a sua própria posição de tu, atestar a presença de um sujeito. (Barros, 2014).

Barrros (2014) chama a atenção para o movimento corporal de repulsa, que aparece como uma forma peculiar de estar na linguagem, já que esses movimentos são uma maneira defensiva de "dizer" ao outro algo de seu desconforto, de seu espaço invadido por ele.

A autora vai além e atesta que discorda das posições que afirmam que esse movimento se mostra como um impedimento aos investimentos externos, pois o que parece ocorrer não é um não interesse e não investimento externo, mas uma dificuldade de corresponder às expectativas comunicativas do interlocutor. (Barros, 2014).

Barros (2014) aponta que: 
"O "não corporal" representa, em nossa perspectiva, uma resposta de recusa ao contato com o outro, o que indica que algo caiu no campo da percepção do autista, pois só evitamos ou negamos aquilo que tomamos conhecimento". (p. 169).

Esse ponto de vista corrobora com o de Laznik (1995/2011) que entende que as estereotipias autísticas seriam como ruínas de antigas cidades na floresta tropical, pois tanto uma quanto a outra atestam que um trabalho humano ocorreu ali, mas do qual resta somente um rastro.

Laznik (1995/2011) afirma que por momentos o analista assume o lugar do Outro primordial. Mas além dessa ocupação, ele antecipa o sujeito a vir ao interpretar toda produção da criança como para tentar advir a uma ordem simbólica preexistente a ela.

No Seminário 1, Lacan (1953-54/1996) se utiliza de um caso de uma criança autista para fazer debater o estádio do espelho. É interessante retomarmos suas considerações sobre tal caso.

O caso que ele utiliza é o caso Dick que foi descrito por Melanie Klein (1930) no texto "A importância da formação de símbolos no desenvolvimento do ego". Essa criança chegou ao consultório de Melanie Klein aos quatro anos de idade e apresentava pobreza de vocabulário e desenvolvimento intelectual descrito como corresponde ao de uma criança de quinze ou dezoito meses. Ainda apresentava carência de afetos e indiferença frente a presença-ausência da mãe. Não brincava e parecia incapaz de se fazer entender. Também apresentava um comportamento descrito por ela como "negativo", já que, por diversas vezes se recusava a fazer algo que lhe era pedido ou fazia de maneira oposta ao solicitado. 
Klein (1930) entende que a inibição incomum de Dick é fruto de um fracasso das etapas primitivas de seu desenvolvimento, o que parece ter resultado em uma incapacidade constitucional de para tolerar a angústia. Dessa maneira, ao levar em conta essa falha nas operações primitivas, ao longo dos atendimentos, ela interpreta e significa as brincadeiras, falas e gestos de Dick, de maneira que elas passam a ter sentido e operam de maneira constituinte nele.

No caso Dick, o que existe é um esboço de imaginificação do mundo exterior, somente um esboço. Para ele o real e o imaginário são equivalentes. Lacan (1953-54/1996) afirma que é necessário que ocorra uma junção da linguagem e do imaginário do sujeito. No caso de Dick, ele possui linguagem, mas não tem palavra.

Lacan (1953-54/1996) em relação ao caso Dick afirma que as interpretações oferecidas por Melanie Klein determinam uma posição inicial que possibilita o sujeito fazer agir sobre o imaginário e o leva assim a conquistar seu desenvolvimento. É a partir delas que ele mergulha numa série de equivalências, num sistema onde os objetos substituem uns aos outros.

Em relação à clínica do autismo, Jerusalinsky, A. (1984/2012) ressalta que ela faz com que o analista procure por uma "janela pulsional" como forma de enlaçar a pulsão desperdiçada em busca de algo que abra brecha para uma identificação (Jerusalinsky, A., 1984/2012).

As interpretações de Melanie Klein (1930), como bem apontadas por Lacan (1953-54/1996), podem ser consideradas um exemplo do uso desta "janela pulsional", já que, a partir da escuta de Dick ela consegue achar uma possiblidade identificação, o que permite uma oferta de significação a ele.

Sendo assim, a intervenção precoce na clínica do autismo teria por objetivo reconstituir o circuito pulsional da criança. Para tal é necessário uma escuta 
para identificar a cadeia significante que a criança apresenta e não a do adulto que a atende, pois senão seria mais uma invasão, e, logo, uma não escuta a esse sujeito. 


\section{CAPÍTULO 4 - Maternidade e autismo}

A maternidade por si só já representa um momento angustiante. É nela que são projetadas e vividas as fantasias em torno do filho que está para nascer; e são vivenciadas as questões fálicas.

Para poder formar o "corpo" mãe/bebê a mãe passa por uma gama de mudanças físicas, experiencia emoções fortes e passa por vivências psíquicas tanto positivas quanto negativas, sendo essas extremamente complexas e carregadas de sentimentos ambivalentes (Veneziani, 2014).

Durante a gestação é esperado que a mulher se encontre em um trabalho de luto das perdas necessárias para tornar-se mãe, o que pressupõe uma ressignificação de suas questões edípicas e de sua feminilidade. Neste tempo de processamento de perdas, ou seja, um estado depressivo, a mãe se encontra de tal modo centrada psiquicamente nesse processo, que se utiliza de toda sua libido (Veneziani, 2014).

Souza (2014) ressalta que a mãe deseja um filho como que por uma evocação alucinatória, de algo de sua própria infância que foi perdida. A mãe tenta a partir do bebê, esse pedaço de carne que nasceu separado dela, sobrepor sobre ele uma imagem fantasmática que terá o papel de reduzir sua decepção, de sua própria história, de algo que foi perdido em sua infância.

Se a mãe conseguir realizar esse trabalho de luto de maneira bem sucedida, sua libido estará liberada para investir em um novo objeto: o seu bebê. É necessário que esse processo ocorra, pois ao nascer o bebê é retirado do puro orgânico, e precisa ser acolhido em um berço simbólico, sendo amparado por 
palavras e desejos (Veneziani, 2014). É aquela que exerce a função materna que irá ocupar o lugar de agente de intermediação simbólica para o infans.

As identificações do bebê são orientadas pelo desejo materno. Desejo articulado na falta materna. Logo as identificações são articuladas no Falo. (Jerusalinsky, A., 1984/2012). Em outras palavras desejar o filho gira em torno de como a mãe se estabelece na própria falta (Jerusalinsky, A., 1984/2012).

A falicização do filho é necessária para que este se constitua, mas não é incomum uma decepção frente a essa criatura que nasce e deveria encarnar o falo, como é próprio de tudo que está sob esse signo. Tanto que são frequentes as mães que deprimem após o nascimento do filho. Kehl (2008) ressalta essa decepção ao afirmar que "O falo, por sua própria condição simbólica, nunca realiza o que promete, de forma que sua presença mobiliza sempre sentimentos ambivalentes." (p. 74).

Contudo, o questionamento é quando o filho vem com características que dificultam ainda mais que ele ocupe esse lugar para a mãe. Como são os casos das deficiências físicas e mentais e do autismo. Veneziani (2014) aponta que o estado que a mãe se encontra na gestação e que requer a elaboração de perdas, pode ser agravado se acompanhado de outras perdas inesperadas.

O autismo tem um quê a mais nessa ferida narcísica materna. A sua indefinição quanto às causas e constantes divergências quanto aos tratamentos, deixam os pais a deriva, buscando se agarrar a qualquer tábua de salvação que lhes deem alguma reposta.

Freud (1914/2010) ressalta em "Introdução ao narcisismo" que o filho ocupa um lugar narcísico para os pais, que a partir dele e por ele podem reviver seu próprio narcisismo infantil. Dessa maneira, buscando esse narcismo perdido, os pais 
sustentam o lugar de vossa majestade o bebê à criança como forma de reviverem a época em que eles mesmos ocuparam esse lugar.

Não é sem motivo que um dos principais sintomas autísticos dos quais os pais, em especial as mães, se queixam são a aparente falta de interesse do filho por eles e a evitação do olhar. Essa aparente indiferença da criança provoca sentimentos muito intensos nos pais, geralmente entendidos como falta de amor por parte do filho, o que faz com que seja muito difícil investir e olhar para a criança como portadora de seu próprio narcisismo.

Os autistas com frequência são comparados às "crianças-fadas" ou changelings, personagem do folclore irlandês. Na lenda é relatado que criaturas mágicas, sejam duendes, fadas ou trolls, roubam um bebê humano e deixam em seu lugar o seu próprio bebê, um changeling. Essas crianças trocadas são relatadas como apáticas e com comportamentos estranhos, fazendo com que os pais humanos sejam assombrados pela constante sensação de que seu bebê real foi trocado por essa criatura que ali veem.

Os irmãos Grimm, na terceira parte do conto os duendes, descrevem uma dessas trocas: "Os duendes então levaram uma criança para longe de sua mãe, e deixaram em seu lugar um changeling com uma grande cabeça e olhos arregalados, que nada fazia além de comer e beber.” (Grimm, Grimm, 1812/2006, tradução nossa).

Essa comparação não é de forma alguma descabida. As crianças-fadas geralmente são descritas com várias características que lembram os sintomas autísticos, mas além dessa semelhança o que é mais interessante nessa comparação é o lugar ocupado pelos pais: inconformismo com o fato de aquilo que Ihe apresentam seja proveniente deles. É uma ilustração do sentimento de 
narcisismo ferido que é ter um filho autista. "Logo, meu filho não está bem, e eu estou péssima!" (Souza, 2014, p. 279).

A constante busca pela causa do autismo, em especial, no âmbito orgânico tem um quê de desejo de se eximir de culpa e em alguns casos de se eximir da responsabilidade pelo que é percebido no filho. Essa fuga é compreensível, ela comparece como uma defesa ao que vem atacar o narcisismo parental. Todavia, o resultado dessa desimplicação tem consequências catastróficas no par mãe/bebê, sendo que quem sofrerá os maiores prejuízos será o bebê que precisa que esse outro olhe para ele e seja seu guia.

\subsection{Intervenção clínica e os pais}

Tanto Laznik (1995/2011), quanto Kupfer, Faria e Keiko (2007) entendem que a clínica do autismo é a clínica do não saber. Jerusalinsky. A. (1984/2012) corrobora com essa ideia ao afirmar que o trabalho com o autista é um desafio, pois é trabalhar fora do mundo da linguagem, ou seja, é trabalhar com uma criança que opera em uma lógica outra.

Para que o trabalho com o autista ocorra, é necessário se aventurar em seu mundo em busca de algo que lhe permita uma identificação, sendo que esse acesso a ele pode ter início que seja, pela reprodução, imitação dos automatismos dele de forma a possibilitar um olhar àquilo que lhe parece semelhante. Em outras palavras, é construir uma ponte de palavra entre ele e o mundo, nem que esse mundo seja aquele do setting clínico inicialmente. (Jerusalinsky, A., 1984/2012). 
Jerusalinsky (1984/2012) ressalta que no trabalho com o autista é necessário adentrar o território especular com a esperança de que ocorra um retorno a esse território. Para isso ele afirma que é fundamental que ocorra uma penetração no campo parental-filial, de forma que quando esse retorno ocorrer, os pais possam estar disponíveis para fazer o papel de espelho para a criança.

O intuito na clínica do autismo é buscar recuperar, reparar um tempo constitucional que não foi bem sucedido. Para que isso ocorra é necessário que os pais se engajem nesse movimento e que ocorra uma compensação do "tempo perdido". Para isso Jerusalinsky, A. (1984/2012) ressalta a importância da eficácia da "compensação materna" na clínica, que mesmo "fora de época", exerce uma função fundadora no processo de constituição psíquica da criança.

Ao assumir esse trabalho inicial de tradutor é possível permitir aos pais que vejam a criança em seu brilho, onde antes só viam dejeto. De forma que a mãe possa encontrar sua capacidade de ilusão antecipatória, que Ihe irá permitir atribuir significação onde só existe massa sonora (Laznik, 1995/2011). O analista pode funcionar como um tradutor para a criança, onde o gesto passa a ser ato e o som passa a ser fonema (Laznik, 1995/2011).

Nesses casos o analista tem de ocupar um lugar semelhante ao de um espelho, de forma que a mãe possa ver surgir uma imagem unificada de seu filho e investi-la libidinalmente de acordo com um ideal possível para ela. (Laznik, 1995/2011).

O engajamento parental no tratamento psicanalítico é essencial para que o trabalho com a criança tenha frutos, contudo na clínica do autismo tem um outro cuidado que deve ser tomado. Laznik (1995/2011) aponta que o autismo do filho costuma ser vivido pela mãe como um grande fracasso, o que faz com que seja 
muito difícil para ela suportar que um outro possa cuidar dele em seu lugar. Dessa forma, é necessário que se tenha cuidado para que esse cuidado do analista não surja como uma insígnia desse fracasso materno.

O processo de responsabilização dos pais, em especial com crianças autistas, permite que eles possam entrar em cena, não só para auxiliar seu filho que precisa de um outro que o sustente imaginária e simbolicamente, como uma forma de trabalhar junto ao narcisismos ferido e tendência a culpabilização dos pais. Ao poder ser agente do processo de melhora do filho os pais podem se apoderar de um saber sobre essa criança, o que permite que seja possível se identificar com ela e consequentemente reconhecê-la como parte deles mesmos.

\section{2 Caso Gabriel: os efeitos da responsabilização parental no tratamento de uma criança autista}

Gabriel aos três anos de idade foi diagnosticado com transtorno do espectro autista. Na época o grau de seu autismo foi avaliado como grave. Quando iniciou o tratamento ele apresentava comportamento masturbatório constante, evitação do olhar, grande agitação e gritava constantemente. Também tinha o hábito de se agredir e chorava muito.

Ele é filho de um jovem casal, Márcio e Simone e é fruto de uma gravidez gemelar bivitelina, tendo um irmão chamado Guilherme. A procura pelo tratamento ocorreu após queixas da escola onde Gabriel estudava sobre seus comportamentos classificados como estranhos. 
Eles foram orientados a procurar um neuropediatra, que deu o diagnóstico de autismo. Em seguida, ele foi encaminhado para atendimento psicológico e fonoaudilógico. Também foi encaminhado à estimulação precoce na Secretaria de Educação do Distrito Federal e à equoterapia.

Após cinco meses sendo atendido por outra profissional, Gabriel foi encaminhado a mim, e permanece em atendimento até o presente momento. De início atendia-o uma vez por semana, tendo o número de sessões semanais aumentado para duas após alguns meses.

O trabalho com Gabriel de início foi de fisgar seu olhar tomando sempre muito cuidado para não invadí-lo. O outro era muito invasivo para ele. Entretanto, ao longo do acompanhamento, ele passou a se interessar por esse outro que ali estava disposto a escutá-lo.

Além das sessões com a criança, eram realizadas reuniões com os pais, que se configuravam como um lugar onde eles podiam falar de sua angústia e buscar orientações sobre um saber fazer junto a Gabriel. Os pais sempre falavam da dificuldade que tinham em conversar com o filho. A maior parte das brincadeiras eram corporais e pouco se falava com ele ou por ele.

Simone é funcionária pública e possui uma grande carga de trabalho que a impede de ficar muito tempo com os filhos, enquanto Márcio tem o próprio negócio e consegue flexibilizar seus horários. Dessa forma, Márcio assumiu a frente dos cuidados com os filhos e o acompanhamento de Gabriel, além da terapia e diversas atividades terapêuticas que participa.

Contudo, Márcio assumiu mais do que a pura responsabilidade de acompanhar e cuidar de Gabriel, ele assumiu a função materna, antes pouco 
ocupada. A partir da ocupação desse vácuo materno,. esse pai cheio de afeto passou a se ocupar tanto de Gabriel quanto do irmão.

De início ele apresentava muita preocupação sobre o quê e como fazer. Com o passar do tempo foi possível observar uma mudança em seu discurso. A proximidade fez com que ele ficasse seguro e passasse a falar por Gabriel. Os atos, sentimentos e birras passaram a ser traduzidos, significados. Gabriel passou a ter vontades, preferências, gênio, manias.

O caso de Gabriel é interessante, pois representa um exemplo dos efeitos que a responsabilização paterna pode exercer no tratamento da criança. Seus pais, ao serem convocados, e elucidados da importância de seu papel para a constituição de seu filho, realizaram um reposicionamento frente a essa criança.

Gabriel deixou o estatuto do desenvolvimento e saúde orgânica, para o desejo de afeto e enlaçamento pulsional frente aos seus pais. A partir do momento que ele deixa o registro do orgânico, ou seja, do inevitável e incurável, e adentra um território de esperança, seus pais passam crer e esperar que Gabriel, junto e por eles, se constitua.

Podemos afirmar que a continuidade do processo de constituição de Gabriel e seus contundentes ganhos em consequência deste, só foram possíveis por causa do amor de seus pais, pois a partir do engajamento e comprometimento com Gabriel, eles puderam olhar para seu filho e reconhecer ali uma parte deles mesmos.

Gabriel atualmente está com cinco anos de idade. Ele é uma criança ativa, carinhosa e muito sorridente. Está estudando em uma classe TGD (Transtorno Global do Desenvolvimento) em uma escola da Secretaria de Educação e é o "xodó" 
dos colegas da escola. Conhece e participa ativamente da rotina escolar, de onde só tem elogios.

Continua com a equoterapia e é destaque na natação. Retomou acompanhamento fonoaudiólogico e já fala várias palavras, mas mesmo quando essas Ihe faltam, ele consegue mostrar e solicitar ao outro o que deseja. Vem sempre surpreendendo e continuará a surpreender, afinal tem um outro ali esperando por ele. 


\section{CONCLUSÃO}

Por mais que o significado da maternidade tenha sofrido alterações ao longo dos anos, ela ainda representa um lugar importante na vida mulher. A vantagem das mudanças que sofreu é que ela saiu do posto de grande realização pessoal feminina, para o lugar de uma possibilidade, uma escolha, que não necessariamente exclui as demais.

Contudo, não é possível negar que, mesmo com novas possibilidades saídas fálicas, a mulher ainda é muito cobrada culturalmente para não só ocupar, como corresponder às expectativas desse lugar de mãe.

Dar conta dessas expectativas é uma tarefa da ordem do impossível, afinal o trabalho materno é hercúleo, e como bem disse Winnicott (1956/1997), não é interessante que essa mãe seja toda, só é necessário que ela seja suficientemente boa.

A mãe ou aquele que exerce a função materna tem papel central na vida da criança da qual ela se ocupa. É esperado que ela, a pessoa que desempenhará essa função, seja ocupada por essa criança também. Não é possível tomar esse lugar sem se doar a ele.

Essa função é fundamental para que do puro automatismo orgânico, do qual o bebê está instalado ao nascer, advenha um sujeito (Jerusalinsky, A., 1984/2012). Essa transição possibilitada pela função materna é muito complexa e pouco previsível, já que nesse processo estão envolvidos não só as fantasias e o desejo materno, bem como a disponibilidade do bebê.

Jerusalinky, A. (2014) ressalta bem essa complexidade: 
"Por sua parte a psicanálise já tinha estabelecido no campo da causalidade o princípio de sobredeterminação próprio do conceito de série operada pela função. Assim, as séries complementares formuladas por S. Freud: as condições constitucionais, as experiências infantis e a situação atual configuram de acordo com uma prevalência cambiante e não previamente determinada (muito menos universalmente definida) o campo da causalidade psíquica, ou seja, o modo em que o campo da palavra pode ou não intervir organizando a significação que, a cada momento tem os eventos e acontecimentos na vida de um determinado sujeito." (p. 159160).

Logo, não é possível precisar causa e efeito no psiquismo. Mesmo que o trabalho psicanalítico seja realizado junto à constituição psíquica da criança, ou seja, ao longo desse processo de estruturação, a psicanálise só trabalha com o a posteriori, no só depois. De fato, quando se opera nesse processo é possível observar os efeitos de forma mais clara, mas mesmo assim ele ainda se configura como um mistério cujos efeitos das intervenções só serão passíveis de reconhecimento no só depois.

A clínica com crianças tem a peculiaridade de se pautar em um trabalho em um sujeito ainda em formação. Entretanto no caso do autismo o que se observa é um sujeito que sofreu um curto-circuito nesse processo ficando estagnado em uma fase muito primária, o que se configura como um desafio para aquele que ali irá intervir. 
Toda clínica é pautada na angústia, contudo na clínica do autismo existe o "a mais" de operar em um campo onde não tem uma linguagem estabelecida. É um exercício de mudança de lógica psíquica, que se faz necessário para se fazer disponível à escuta fora da linguagem.

Maleval no texto Escutem os Autistas! (2012) cita um conselho de Jim Sinclair (1993) aos pais dos autistas, contudo podemos considerar que seja uma orientação a todos àqueles que se relacionam com portadores desse funcionamento:

"Nossas formas de entrar em relação são diferentes. Se vocês insistem em coisas que suas expectativas consideram normais, vocês encontrarão frustração, decepção, ressentimento, talvez mesmo raiva e ódio. Aproximem-se respeitosamente, sem prejulgamentos, e abertos a aprender novas coisas, e vocês encontrarão um mundo que jamais teriam imaginado." (p. 2).

Essa fala de Sinclair é interessante, pois convoca os pais ao compromisso de entrar em um outro mundo. Essa convocação se assemelha muito com a posição da clínica psicanalítica de responsabilização dos pais.

Essa responsabilização se mostra benéfica tanto para a criança como para seus pais, já que, possibilita um movimento de sair da posição passiva da incurabilidade, para a implicação com as produções da criança e reconhecimento da importância das figuras parentais para ela.

Do ponto de vista da criança, a ela é permitido que, sob a insígnia da esperança, possa ocupar um lugar outro do que o de dejeto. Passa a ser possível esperar algo dela. Essa esperança só possível, pois os pais podem sair de um lugar 
de passividade frente à condição de seu filho, já que o agir deles passa a ter um valor, ganha sentido.

A intervenção junto a esses pais é sempre no sentido de reconhecimento das produções da criança e uma valorização das etapas já atingidas, já que é comum muitos se desanimarem ao comparar os filhos com outras crianças da mesma idade. Contudo, para além desse reconhecimento das produções infantis, a responsabilização possibilita aos pais, que ao se reconhecerem como participantes da constituição do filho, eles possam se colocar como atuantes nessa relação e se apropriarem dos ganhos e produções do filho como também pertencentes a eles mesmos. Em outras palavras, faz com que seja possível reconhecer nessa criança parte de seu narcisismo e, assim, amá-la.

Outro ponto importante é a necessidade de articulação entre os analistas que se ocupam desse tipo de demanda e os demais profissionais que atendem a criança. Para além de um afinamento entre os trabalhos, o analista tem um papel de instalador da dúvida, já que é tão frequente que esses profissionais se prendam e se deixem seduzir pelo determinismo genético e técnicas de adaptação.

Essa articulação para além de ser informativa se faz necessária como instalação desse olhar disponível frente à criança, de maneira que eles também possam passar a valorizar suas produções.

O trabalho com os pais também passa por uma descoberta deles mesmos, de como serem pais, de como se posicionarem frente aos filhos. $\mathrm{O}$ analista acaba auxiliando os pais a encontrarem seu próprio saber e seu modo de estar nessa relação com seu filho. As orientações oferecidas aos pais passam longe de uma catequese ou kwon-how, mas funcionam como um desenho por colorir, onde os traços existem, mas são coloridos conforme gosto e estilo. 
Dessa maneira, o que deve ser norteador no tratamento com crianças autistas na clínica psicanalítica, é garantir um tempo de infância considerando e respeitando a fragilidade materna. Em outras palavras, intervir junto à criança e aos pais, de forma a não invadir tanto a criança, quanto a fragilidade do conjunto parental. 


\section{REFERÊNCIAS BIBLIOGRÁFICAS}

André, Serge. (2011) O que quer uma mulher?. Rio de Janeiro: J. Zahar (Original publicado em 1986).

Barros, Isabela Barbosa do Rêgo (2014) A linguagem como lugar de enunciação do sujeito autista (167-176). In: Muratori, Felippo. (Org.); Lerner, Rogério. (Org.). Os enlaces do corpo e da escrita na criança e no adolescente. 1. ed. São Paulo: Instituto Langage, v. 1. 384 p.

Birman, Joel. (2001) Gramáticas do erotismo: a feminilidade e as suas formas de subjetivação em psicanálise. Rio de Janeiro: Civilização Brasileira.

Catão, Inês.(2014) Por um desenvolvimento psíquico sustentável: o corpo como resposta à invocação do Outro. (235-247) In: Muratori, Felippo (Org.); Lerner, Rogério. (Org.). Os enlaces do corpo e da escrita na criança e no adolescente. 1. ed. São Paulo: Instituto Langage, v. 1. 384 p.

Cavalcanti, Ana Elizabeth; Rocha, Paulina Schmidtbauer. (2001). Autismo: construções e desconstruções. São Paulo: Casa do Psicólogo.

Cristina Kupfer, M.. (1999). Psicose e autismo na infância: problemas diagnósticos. Estilos da Clinica, 4(7), 96-107. Recuperado em 11 de setembro de 2014, de http://pepsic.bvsalud.org/scielo.php?script=sci_arttext\&pid=S1415$71281999000200010 \& \operatorname{lng}=$ pt\&tlng=pt.

Cullere-Crespin, Graciela. (2004). A clínica precoce: contribuição ao estudo da emergência do psiquismo no bebê. In: A clínica precoce: o nascimento do humano. São Paulo: Casa do Psicólogo.

Cullere-Crespin, Graciela. (2004). Os sinais de sofrimento precoce. In: A clínica precoce: o nascimento do humano. São Paulo: Casa do Psicólogo.

Debray, Rosine. (1988). A alimentação: comer demais ou muito pouco. In: Bebê/Mães em revolta. Porto Alegre: Artes Médicas.

Dolto, Françoise (1996). Sexualidade Feminina. São Paulo: Martins Fontes (Original publicado em 1984). 
Ferreira, Severina Sílvia. (2014) Autismo e declaração de guerra à Psicanálise. In: Muratori, Felippo (Org.); Lerner, Rogério. (Org.). Os enlaces do corpo e da escrita na criança e no adolescente. ( $1^{a}$ ed). (pp. 177-84). São Paulo: Instituto Langage, v. 1. $384 \mathrm{p}$.

Freud, Sigmund. (2010) Conferências introdutórias à Psicanálise. In: Obras completas, v. 18. (pp. 123-354). Tradução e notas Paulo César de Souza. São Paulo: Companhia das letras, (Original publicado em 1933).

Freud, Sigmund. (2006) Três Ensaios sobre a Sexualidade (1905), In: Freud Sigmund. Edição Standart Brasileira das Obras Psicológicas de Sigmund FreudUm Caso de Histeria, Três Ensaios Sobre a Sexualidade e Outros Trabalhos (1901 1905) (pp.119-231). RJ: Imago V. VII(Original publicado em 1905).

Freud, Sigmund. (2010) A organização genital infantil. In: Obras completas, v. 16. (pp.168-175). Tradução e notas Paulo César de Souza. São Paulo: Companhia das letras (Original publicado em 1923).

Freud, Sigmund. (2010) Dissolução do complexo de Édipo. In: Obras completas, $v$. 16. (pp. 203-213). Tradução e notas Paulo César de Souza. São Paulo: Companhia das letras, (Original publicado em 1924).

Freud, Sigmund. (2010) Algumas consequências psíquicas da diferença anatômica entre os sexos. In: Obras completas, v. 16. (pp. 283-299). Tradução e notas Paulo César de Souza. São Paulo: Companhia das letras. (Original publicado em 1925).

Freud, Sigmund. (2010) Introdução ao narcisismo (1914). In: Freud, Sigmund. Obras Completas, v. 12. (pp. 13-50). São Paulo: Companhia das Letras (Original publicado em 1914).

Freud, Sigmund. (2006). Projeto para uma psicologia científica. In: Edição Standard Brasileira das Obras Psicológicas Completas de Sigmund Freud. (pp. 421-22). Rio de Janeiro: Imago, 1977. v. 1. (Original publicado em 1895).

Freud, Sigmund. (2010). Além do princípio do prazer. In: Obras Completas, v 14. (pp. 161-239). Tradução e notas Paulo César de Souza. São Paulo: Companhia das letras. (Original publicado em 1920)

Grimm, Jacob; Grimm, Wilhelm. (2006) The Elves. In: Children's and Household Tales by the Brothers Grimm. Tradução de Lucy Crane. (Original publicado em 1812) 
EBook \#19068. Disponível em: <http://www.gutenberg.org/files/19068/19068h/19068-h.htm>

Jerusalinsky, Alfredo. (2012) Psicanálise do autismo. Porto Alegre, Instituto Langage, 2ed. (Original publicado em 1984)

Jerusalinsky, Alfredo. (2014) Como funciona a causalidade psíquica. In: Muratori, Felippo. (Org.); Lerner, Rogério. (Org.). Os enlaces do corpo e da escrita na criança e no adolescente. (1를 ed). (pp.157-166). São Paulo: Instituto Langage, v. 1. 384 p.

Jerusalinsky, Julieta. A criação da criança - letra e gozo nos primórdios do psiquismo. 2009. Tese (Doutorado em Psicologia (Psicologia Clínica)) - Pontifícia Universidade Católica de São Paulo. Orientador: Manoel Tosta Berlinck.

Kehl, Maria.Rita. (2008) Deslocamentos do feminino. (2 ${ }^{\underline{a}}$ ed). Rio de Janeiro: Imago.

Klein, Melanie. (1981). A importância da formação de símbolos no desenvolvimento do ego. In: Contribuições à psicanálise (2 ${ }^{a}$ ed. pp. 295-313). São Paulo: Mestre Jou (Original publicado em 1930)

Kupfer, M. Cristina M., Faria, Carina, \& Keiko, Cristina. (2007). O tratamento institucional do outro na psicose infantil e no autismo. Arquivos Brasileiros de Psicologia, 59(2), 156-166. Recuperado em 9 de agosto de 2015, de http://pepsic.bvsalud.org/scielo.php?script=sci_arttext\&pid=S1809$52672007000200006 \&$ Ing=pt\&tlng=pt. .

Lacan, Jaques. (1998) Diretrizes para um congresso sobre a sexualidade feminina. In: Lacan, Jaques. Escritos. (pp. 734-748) Rio de Janeiro: J. Zahar. (Trabalho original publicado em 1960).

Lacan, Jaques. (1996). O seminário, livro 1: os escritos técnicos de Freud. (B. Milan, Trad.). Rio de Janeiro: Jorge Zahar. (Trabalho original publicado em 1953-54).

Lacan, Jaques. (1988). O seminário, livro 3: As psicoses. Rio de Janeiro: Jorge Zahar. (Trabalho original publicado em 1955-56).

Lacan, Jaques. (2008). O seminário, livro 20: mais, ainda. (M. D. Magno, Trad.). Rio de Janeiro: Jorge Zahar. (Trabalho original publicado em 1972-73) 
Laznik, Marie-Christine. (2004) A voz da sereia: O autismo e os impasses na constituição do sujeito. Salvador: Ágalma.

Laznik, Marie-Christine. (2011) Rumo à fala - três crianças autistas em psicanálise. Rio de Janeiro: Cia de Freud editora (Original publicado em 1995).

Maia, Ruskaya Rodrigues. Uma contribuição lacaniana à teoria da feminilidade: a teoria da devastação. 2005. 105 f. Dissertação (Mestrado em Psicologia) Universidade de Brasília. Orientador: Luiz Augusto Monnerat Celes.

Maleval, Jean-Claude, (2012) Escutem os autistas! (Tadução de Maria do Rosário Cavalcanti Oliveira. Original disponível em:

<http://ebpdelegacaogeralgodf.blogspot.com.br/2012_07_01_archive.html

Neri, Regina. (2005) A psicanálise e o feminino: um horizonte de modernidade. Rio de Janeiro: Civilização Brasileira.

Organização Mundial da Saúde. (1997) CID-10 Classificação Estatística Internacional de Doenças e Problemas Relacionados à Saúde. (10a ver). São Paulo: Universidade de São Paulo; vol.1.

Solomon, Andrew. (2013) Longe da árvore: pais, filhos e a busca da identidade. Tradução de Donalson M. Garschagen, Luiz A. de Araújo, Pedro Maia Soares. (1 ${ }^{\underline{a}}$ ed). São Paulo: Companhia das Letras.

Souza, Fabiana Josefa do Nascimento. (2014) "Meu filho não está bem!" O movimento do desejo na relação pais e filhos na clínica psicanalítica com crianças; In: Muratori, Felippo. (Org.); Lerner, Rogério. (Org.). Os enlaces do corpo e da escrita na criança e no adolescente. (1를 ed). (pp. 273-281). São Paulo: Instituto Langage, v. $1.384 \mathrm{p}$.

Veneziani, Josênia. (2014) Depressão na gravidez. In: Muratori, Filippo. (Org.); Lerner, Rogério. (Org.). Os enlaces do corpo e da escrita na criança e no adolescente. (1 ${ }^{\text {a }}$ ed). (pp. 283-298). São Paulo: Instituto Langage, v. 1. 384 p.

Winnicott, Donald Woods. (1978). Preocupação materna primária. In: Textos selecionados: da pediatria à psicanálise. Rio de Janeiro: Francisco Alves. (Original publicado em 1956) 
Winnicott, Donald Woods. (1997). A influência do desenvolvimento emocional sobre os problemas de alimentação. In: Pensando crianças. Porto Alegre: Artmed (Original publicado em 1967). 